\title{
Leguminosae no Parque Natural Municipal de Jacarenema, Vila Velha, Espírito Santo, Brasil
}

\author{
Lucas de Almeida Silva, Luciana Dias Thomaz \& Valquíria Ferreira Dutra
}

Universidade Federal do Espírito Santo, Departamento de Ciências Biológicas, Av. Fernando Ferrari 514, CEP 29075-91, Vitória,Espírito Santo, Brasil. lucasdealmeida1990@gmail.com

Recebido em 04.X.2016

Aceito em 22.X.2018

DOI 10.21826/2446-8231201873305

\begin{abstract}
RESUMO - O Parque Natural Municipal de Jacarenema (PNMJ) é uma área de restinga que ainda possui fragmentos de comunidades conservadas, localizado na área urbana da cidade de Vila Velha, ES. Apesar da importância de Leguminosae, nenhum levantamento envolvendo toda a família para as restingas do Espírito Santo havia sido realizado. O presente estudo visou preencher esta lacuna de conhecimento, fornecendo informações sobre a diversidade de Leguminosae para este trecho de restinga. Foram registrados 53 táxons incluindo 29 gêneros, 51 espécies, 3 subespécies e 4 variedades taxonômicas, sendo que destes, 24 táxons são novas citações para as restingas capixabas e 37 ainda não haviam sido citados para a flora do PNMJ. São apresentados chave de identificação, descrições, ilustrações e comentários sobre distribuição, habitat, fenologia e taxonomia.
\end{abstract}

Palavras-chave: Fabaceae, flora, restinga, taxonomia

ABSTRACT - Leguminosae on Parque Natural Municipal de Jacarenema, Vila Velha, Espírito Santo, Brazil. Jacaranema’s Municipal Natural Park is an area that still has fragments of conserved restinga communities, located in an urban area of the city of Vila Velha. Despite the importance of the family, no exclusive survey about the Leguminosae of Espírito Santo's restingas has been performed yet. The present study aims to fill this knowledge gap by providing information about the diversity of Leguminosae for this area. Fifty three taxa distributed within 29 genera, 51 species, three subspecies and four varieties, and 24 of these taxa are new citations for Espírito Santo's restingas, and 37 for the park's flora. Here we present an identification key, descriptions, illustrations and comments about distribution, habitat, phenology and taxonomy of the recorded species.

Keywords: Fabaceae, flora, restinga, taxonomy

\section{INTRODUÇÃO}

Leguminosae é a terceira maior família das angiospermas, com 730 gêneros e 19.400 espécies, muitas delas de grande importância econômica, distribuídas por todos os hábitats terrestres (Polhill et al. 1981, Lewis et al. 2005). No Brasil está representada por 2.756 espécies e 222 gêneros (BFG 2015) e no Espírito Santo por 384 espécies e 114 gêneros (Dutra et al. 2015). A família é citada como uma das mais diversas nos levantamentos realizados nas restingas, tanto no Espírito Santo (Pereira \& Araújo 2000, Valadares et al. 2011, Souza et al. 2016), quanto nos demais Estados do Brasil (Martins et al. 2008, Santos-Filho 2009, Araújo et al. 2009, Dantas et al. 2010).

As restingas constituem o conjunto das comunidades que ocorrem sobre depósitos arenosos costeiros e recobrem aproximadamente $5.000 \mathrm{~km}$ do litoral brasileiro, o que corresponde a 79\% de sua extensão (Cerqueira 2000). Apresentam uma flora composta por espécies de diferentes ecossistemas, como da Mata Atlântica e da Floresta Amazônica, e também por elementos endêmicos (Araújo \& Lacerda 1987), normalmente adaptados a altos índices de salinidade e a um solo que retém pouca umidade e nutrientes (Pereira 1990). Assim, cada restinga tem suas particularidades florísticas devido ao caráter único da sua formação, ligado, sobretudo a aspectos geomorfológicos (Cerqueira 2000).

Embora ameaçadas, as restingas espiritossantenses são pouco estudadas e o conhecimento botânico existente se resume a alguns estudos ecológicos e florísticos (Fraga \& Peixoto 2004, Magnago et al. 2011, 2012); a trabalhos sobre a fisiologia das plantas ocorrentes na restinga (Neves et al. 2009, Siqueira-Silva et al. 2012); a alguns levantamentos florísticos e fitossociológicos (Fabris 1995, Fabris \& Cesar 1996, Pereira \& Zambom 1998, Pereira et al. 1998, 2000, Pereira \& Assis 2000, Assis et al. 2004a,b, Colodete \& Pereira 2007, Valadares et al. 2011) e a registros de novas espécies (Santos-Gonçalves et al. 2011, Ribeiro et al. 2015). Existem ainda alguns estudos taxonômicos, como o de Weiler Jr. (1998), sobre as Leguminosae: Papilionoideae, o de Fabris \& Peixoto (2013), sobre as Sapotaceae e o de Valadares \& Sakuragui (2016), sobre as Araceae, além de flórulas de parques, como as realizadas por Valadares et al. (2010), Chagas et al. (2014) e Peterle et al. (2015) no Parque Estadual Paulo César Vinha, no município de Guarapari, com o gênero Anthurium Schott (Araceae) 
e as subfamílias de Leguminosae Caesalpinioideae e Mimosoideae, respectivamente.

Considerando as lacunas no conhecimento taxonômico das restingas espiritossantenses, este trabalho teve como objetivo o estudo das espécies de Leguminosae do Parque Natural Municipal de Jacarenema, com a elaboração de chave de identificação, descrições e ilustrações dos táxons específicos e infraespecíficos listados, representando o primeiro estudo taxonômico realizado neste parque. A riqueza de espécies encontrada para a família mostra a importância da preservação da área do Parque.

\section{MATERIAL E MÉTODOS}

No estado do Espírito Santo o ecossistema restinga pode ser encontrado ao longo de cerca de $370 \mathrm{~km}$ de costa (Thomaz \& Monteiro 1993), interrompida em alguns pontos pelos tabuleiros e pelas formações Pré-cambrianas (Moreira \& Camelier 1977). Tal ecossistema, embora classificado por lei como área de preservação permanente e protegido através da criação de Unidades de Conservação, ainda é bastante ameaçado, principalmente pela especulação imobiliária e extração de areia (Maciel 1990).

A heterogeneidade florística das restingas conduz à ocorrência de diferentes fitofisionomias que podem ser classificadas, segundo Magnago et al. (2011), em: herbácea não inundável, herbácea inundável, herbácea inundada, arbustiva fechada não inundável, arbustiva fechada inundável, arbustiva aberta não inundável, arbustiva aberta inundável, floresta não inundável, floresta inundável, floresta inundada, palmae e dunas. Terminologia que foi adotada neste trabalho.

O Parque Natural Municipal de Jacarenema (PNMJ) possui uma área de 307 hectares (IPEMA 2005) e está localizado no entorno das coordenadas $20^{\circ} 26^{\prime} 25^{\prime} \mathrm{S}$ e $40^{\circ} 18^{\prime} 45^{\prime}$ 'W, no bairro da Barra do Jucu, no município de Vila Velha, estado do Espírito Santo (Fig. 1). Segundo dados do INCAPER obtidos na estação meteorológica do INMET/Vitória-ES, o clima da região é classificado, segundo Köppen, como tipo Aw tropical, com verões quentes e chuvosos e invernos frios e secos.

As coletas de material botânico foram realizadas mensalmente, no período de agosto de 2010 a junho de 2013, ao longo de trilhas e das estradas do Parque, cobrindo a maioria das formações vegetais existentes.

Os materiais coletados foram preparados de acordo com as técnicas usuais de herborização (Fidalgo \& Bononi 1989) e, após identificação, foram depositados no acervo do Herbário VIES, do Departamento de Ciências Biológicas, da Universidade Federal do Espírito Santo, Vitória, ES.

A identificação dos espécimes foi realizada através de chaves analíticas, diagnoses, descrições, ilustrações presentes na literatura e consulta às coleções depositadas nos Herbários VIES, MBML, CVRD e RB (acrônimos conforme Thiers 2011). A classificação adotada para subfamílias e gêneros está de acordo com Lewis et al. (2005).

O tratamento taxonômico para as espécies amostradas consistiu na elaboração de diagnoses morfológicas, ilustrações e chave para identificação dos táxons com base nos caracteres vegetativos e reprodutivos. Nos comentários foram apresentados dados sobre a fenologia, hábitats preferenciais e taxonomia.

A terminologia morfológica para as diagnoses foi baseada em Radford et al. (1974), exceto a classificação dos frutos, que foi baseada em Barroso et al. (1999), e a classificação dos nectários, baseada em Fernandes (2011). Os nomes dos autores das espécies estão abreviados de acordo com Brummitt \& Powell (1992). As medidas das estruturas foram realizadas em material herborizado ou reidratado e obtidas na região mediana das estruturas. As diagnoses apresentam a amplitude de variações morfológicas observadas nos caracteres vegetativos e reprodutivos. As ilustrações foram confeccionadas com o auxílio de estereomicroscópio, baseando-se em materiais herborizados e/ou fixados em álcool 70\%.

Foi utilizada lista das espécies da Flora Ameaçadas de Extinção no Estado do Espírito Santo (Simonelli \& Fraga 2007) para a identificação de espécies ameaçadas de extinção.

\section{RESULTADOS E DISCUSSÃO}

Foram inventariados 53 táxons específicos e infraespecíficos de Leguminosae para o PNMJ, reunidos em 29 gêneros, o que corresponde a cerca de 13\% do total de espécies e 24\% dos gêneros listados para o Espírito Santo, segundo Dutra et al. (2015). A subfamília Caesalpinioideae teve 13 táxons amostrados em cinco gêneros e 11 espécies, Mimosoideae reuniu 10 espécies em quatro gêneros e Papilionoideae incluiu 32 espécies dentre 20 gêneros. Nenhuma das espécies listadas para o PNMJ consta na lista de espécies da Flora Ameaçadas de Extinção no Estado do Espírito Santo, segundo Simonelli \& Fraga (2007).

O número de táxons de Leguminosae encontrado neste estudo foi maior que o listado em outras áreas de restinga dos estados do Espírito Santo, Rio de Janeiro, São Paulo, Pernambuco e Sergipe (Gomes 2002, Pereira \& Assis 2000, Sá 1992, Martins et al. 2008, Almeida Jr. et al. 2009, Dantas et al. 2010), embora algumas restingas tenham apresentado riqueza similar ou superior (Weiler Jr. 1998, Araújo et al. 2009, Santos-Filho 2009, Santos-Filho et al. 2011, Souza et al. 2016, Chagas et al. 2014, Peterle et al. 2015), como pode ser observado na Figura 2. Essa ampla diferença encontrada no número de espécies de Leguminosae em diferentes áreas, demonstra a diversidade florística da família entre diferentes restingas, mas também pode ser resultado do tamanho da área amostrada em cada localidade, duração e periodicidade das coletas, como já foi abordado por diferentes autores (Nakajima \& Semir 2001, Romero \& Martins 2002, Dutra et al. 2008). 


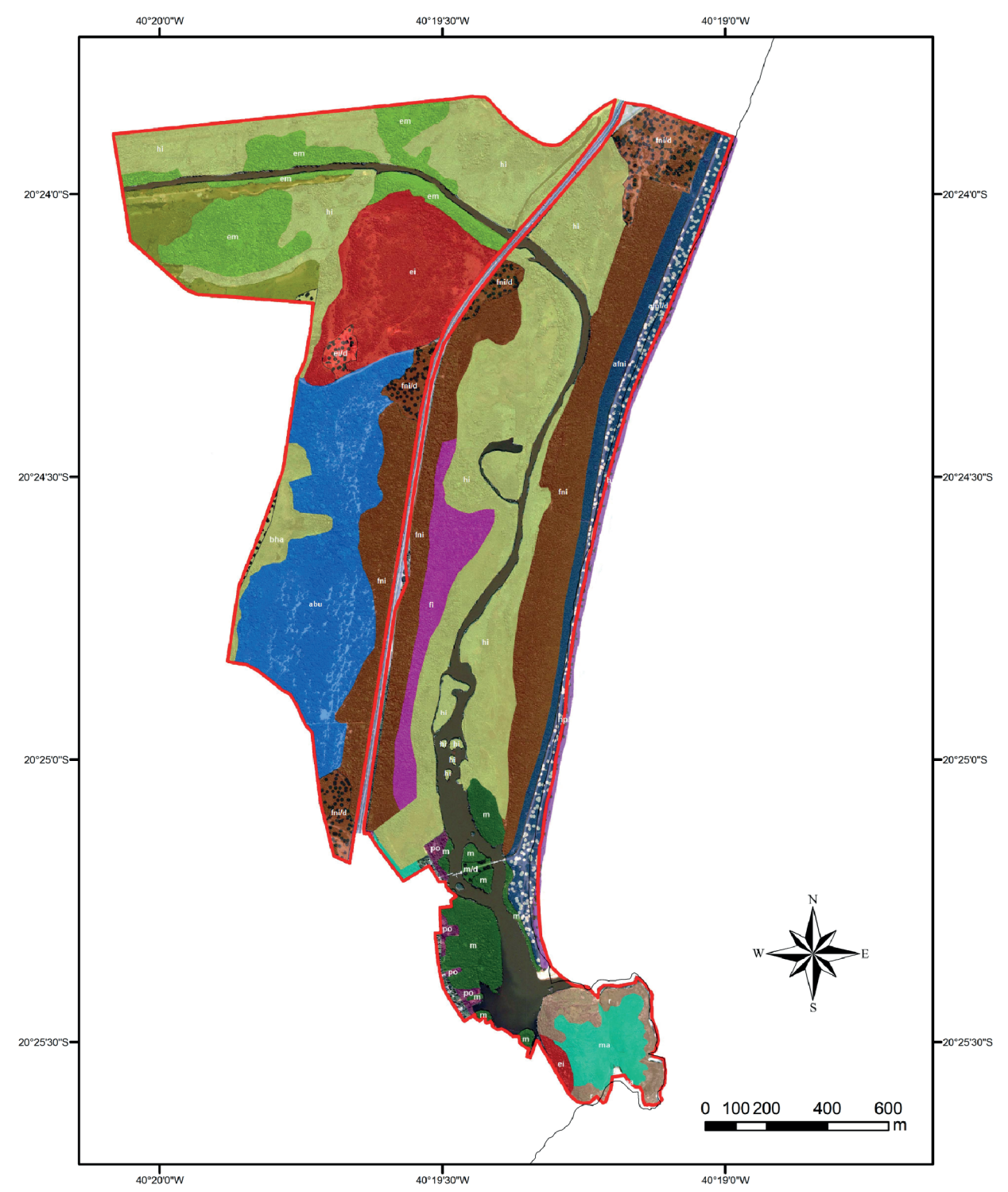

\section{Legenda}
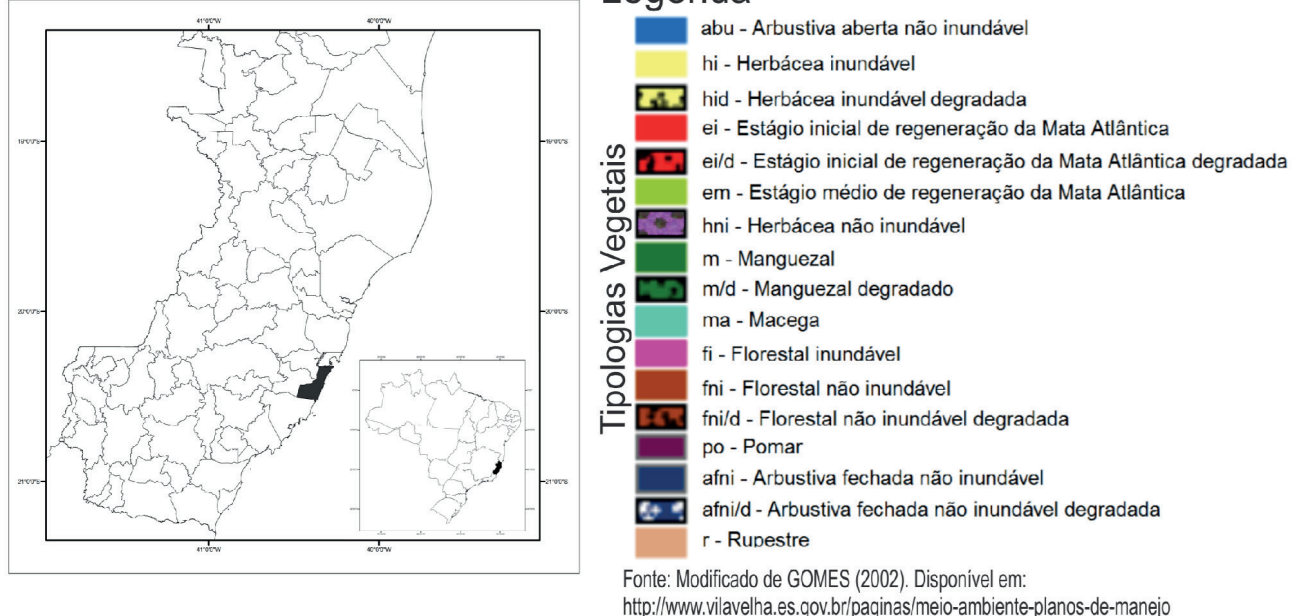

Fig. 1. Localização do Parque Natural Municipal de Jacarenema e suas fitofisionomias. 


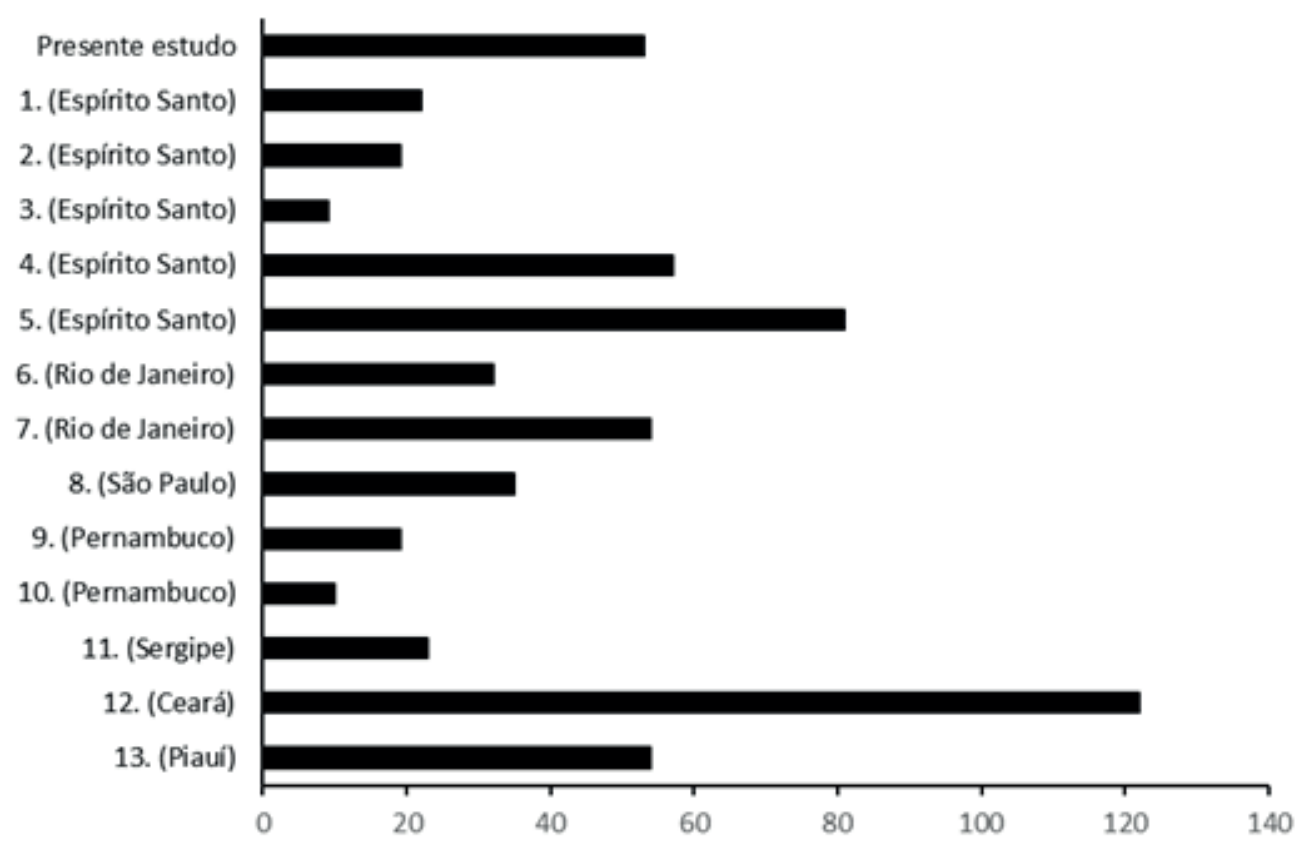

Fig. 2. Comparação entre a diversidade de Leguminosae nas restingas do Brasil. 1. Plano de Manejo do Parque Natural Municipal de Jacarenema, ES (Gomes 2002); 2. Reserva de Camburi, ES (Pereira \& Assis 2000); 3. Morada do Sol, ES (Valadares et al. 2011); 4. Parque Estadual de Itaúnas, ES (Souza et al. 2016); 5. Parque Estadual Paulo César Vinha, ES (Chagas et al. 2014, Peterle et al. 2015, Weiler Jr. 1998); 6. Reserva Ecológica Estadual de Jacarepiá, RJ (Sá 1992); 7. Área de Proteção Ambiental da Massambaba, RJ (Araújo et al. 2009); 8. Bertioga, SP (Martins et al. 2008); 9. Reserva Particular do Patrimônio Natural de Maracaípe, PE (Almeida Jr et al. 2009); 10. Área de Proteção Ambiental de Guadalupe, PE (Cantarelli et al. 2012); 11. Parque Nacional Serra de Itabaiana, SE (Dantas et al. 2010); 12. Ceará (Santos-Filho et al. 2011); 13. Piauí (Santos-Filho 2009).

O número de táxons listados também foi superior ao citado por Gomes (2002) no Plano de Manejo do Parque Natural Municipal de Jacarenema e por Magnago et al. (2012), no estudo fitossociológico realizado no parque, sendo que 36 táxons são novas citações para a flora do parque, o que ressalta a importância de estudos florísticotaxonômicos para o conhecimento da flora. Das espécies citadas por Gomes (2002) como ocorrentes no PNMJ, três não foram confirmadas neste estudo: Anadenanthera sp., Poecilante falcata (Vell.) Heringer e Inga capitata Desv.
Como os materiais-testemunho não foram encontrados em nenhum herbário, não foi possível confirmar a ocorrência das mesmas. Desmodium barbatum (L.) Benth. também citada para a flora do parque, por Gomes (2002), provavelmente, trata-se de D. adscendens (Sw.) DC., pois são espécies semelhantes vegetativamente e Hymenaea rubriflora Ducke trata-se de Hymenaea fariana R.D. Ribeiro, D.B.O.S. Cardoso \& H.C. Lima, espécie semelhante vegetativamente à $H$. rubriflora e que foi recentemente descrita. Segue abaixo a chave para identificação dos táxons.

\section{Chave ilustrada para os táxons de Leguminosae do Parque Natural Municipal de Jacarenema}

1. Folhas 1-folioladas, paripinadas ou imparipinadas.

2. Ervas, subarbustos ou trepadeiras.

3. Folíolos 1-9.

4. Folhas 1-2-folioladas.

5. Folhas 1-folioladas (Fig. 3 A)

3.4 Alysicarpus vaginalis

5'. Folhas 2-folioladas.

6. Folíolos obovados ou elípticos, base oblíqua (Fig. 3 B), flores solitárias (Fig. 3 C), legumes (Fig. 3 D).

7. Estípulas 4-6 mm compr., folíolos ca. $25 \mathrm{~mm}$ compr., pétala vexilar interna ca. $11 \mathrm{~mm}$ compr. 1.6 Chamaecrista rotundifolia var. grandiflora

7’. Estípulas 7-9 mm compr., folíolos 6,7-15 mm compr., pétala vexilar interna ca. 3,8 mm compr. 1.7 Chamaecrista rotundifolia var. rotundifolia 6'. Folíolos lanceolados, base acuminada (Fig. 3 E), inflorescências espiciformes (Fig. 3 F), lomentos (Fig. $3 \mathrm{G})$ 3.32 Zornia glabra

4'. Folhas 3-9 folioladas.

8. Estípulas soldadas, amplexicaules (Fig. $3 \mathrm{H}$ ).

9. Estípulas 3-4 mm compr., 
10. Ramos glandulosos, pecíolos ca. $1 \mathrm{~mm}$ compr., vexilo ca. 9,6 mm compr. ...... 3.28 Stylosanthes viscosa 10’. Ramos não glandulosos, pecíolos ca. 3,5 mm compr., vexilo ca. $5 \mathrm{~mm}$ compr.

9'. Estípulas 7-15 mm compr.,

11. Ramos glandulosos, pecíolo 5-7 mm compr. (Fig. 3 I)

3.24 Stylosanthes debilis

11'. Ramos não glandulosos, pecíolo ca. $3 \mathrm{~mm}$ compr. (Fig. $3 \mathrm{~J}$ ).

12. Estípulas 10-11 mm compr., ovários ca. 3,8 mm compr., lomentos grabros ... 3.25 Stylosanthes gracilis 12'. Estípulas 13-15 mm compr., ovários ca. $1 \mathrm{~mm}$ compr., lomentos puberulentos nas bordas

8'. Estípulas livres.

3.26 Stylosanthes guianensis

13. Folíolos 3.

14. Corola amarela, legumes inflados (Fig. $3 \mathrm{~K}$ ).

15. Estípulas lineares (Fig. $3 \mathrm{~K}$ ), folíolos 19-31 mm compr., legumes tomentosos

3.12 Crotalaria maypurensis

15'. Estípulas filiformes (Fig. $3 \mathrm{M}$ ) a triangulares, folíolos 35-54 mm compr., legumes glabros (Fig.

$3 \mathrm{~L})$ a esparso-puberulentos ....................................................................... 3.13 Crotalaria pallida

14'. Corola branca, vinácea, rosa ou lilás, legumes planos (Fig. 3 N) ou lomentos (Fig. 3 O).

16. Legumes não costados ou lomentos

17. Pecíolos 0,5-14 mm compr.,

18. Estípulas 4-5 mm compr., raque foliar pubescente a puberulenta, lomentos

3.15 Desmodium adscendens

18'. Estípulas 1,4-1,7 mm compr., raque foliar com glândulas puntiformes, legumes (Fig. 3 Q) .....

3.21 Rhynchosia phaseoloides

17'. Pecíolos 17-50 mm compr.

19. Flores ressupinadas, carenas não espiraladas

19'. Flores não ressupinadas, carenas espiraladas

3.10 Centrosema virginianum

20. Estípulas 7,5 mm compr., alas ca. $23,5 \mathrm{~mm}$ compr.

3.20 Macroptilium lathyroides

20'. Estípulas 2-3 mm compr., alas ca. $15 \mathrm{~mm}$ compr. 3.5 Ancistrotropis peduncularis

16'. Legumes costados (Fig. 4 A).

21. Pecíolos 6-10 mm compr., folíolos amplamente ovados

21'. Pecíolos 30-45 mm compr., folíolos elípticos

3.9 Canavalia rosea

13'. Folíolos 4-13.

22. Estípulas triangulares (Fig. 4 B), folíolos elípticos, flores papilionadas, lomentos (Fig. 4 C) 3.2 Aeschynomene brasiliana 22'. Estípulas cordadas (Fig. 4 D), folíolos obovados, flores não papilionadas (Fig. 4 E), legumes (Fig. $4 \mathrm{~F})$ 1.5 Chamaecrista ramosa

3'. Folíolos 20-88.

23. Folíolos 20-40.

24. Nectários foliares cupuliformes (Fig. 4 G)

24'. Nectários foliares caliciformes (Fig. $4 \mathrm{H}$ ) 1.3 Chamaecrista nictitans subsp. patellaria

23'. Folíolos 46-88.

25. Folíolos 46-52, ramos híspidos, raque foliar 34-35 mm compr., lomentos ...... 3.1 Aeschynomene americana 25. Folíolos 76-88, ramos glabros, raque foliar ca. $65 \mathrm{~mm}$ compr., legumes 1.2 Chamaecrista flexuosa

2'. Arbustos ou árvores.

26. Nectários foliares presentes.

27. Nectários foliares claviformes (Fig. 4 I).

28. Folhas 4-folioladas, raque foliar 22-24 $\mathrm{mm}$ compr., glabra 1.10 Senna affinis

28'. Folhas 8-folioladas, raque foliar 65-80 mm compr., esparso-puberulenta

27'. Nectários foliares pateliformes (Fig. $4 \mathrm{~J}$ ) ou cupuliformes (Fig. $4 \mathrm{~K}$ ).

29. Folíolos 2-6.

30. Inflorescências caulifloras, flores assimétricas (Fig. 4 L) 1.4 Chamaecrista nictitans subsp. disadena

30'. Inflorescências não caulifloras, flores actinomorfas (Fig. 4 M).

31. Ramos glabros, folhas 2-3 folioladas, inflorescências espiciformes (Fig. 4 P)

1.1 Chamaecrista ensiformis

31 '. Ramos pubescentes a puberulentos, folhas 4-6-folioladas, inflorescências capituliformes.

32. Folíolos 38-50 mm compr., inflorescências 6-8-floras, nectários pateliformes, legumes ca. 8,5 cm compr. (Fig. $4 \mathrm{~N}$ ) 2.10 Zygia latifolia var. glabrata 
32'. Folíolos 108-140 mm compr., inflorescências 18-floras, nectários cupuliformes, legumes 30-45 cm compr. (Fig. 4 O) 2.1 Inga edulis

29'. Folíolos 8-30.

33. Arbustos ou arvoretas 6-8 $\mathrm{m}$ alt., raque foliar $42-58 \mathrm{~mm}$ compr.

2.3 Inga vera subsp. affinis

33'. Arbustos 2,5-3,5 m alt., raque foliar 70-105 mm compr. 2.4 Inga subnuda

26'. Nectários foliares ausentes.

34. Folhas 1-folioladas.

35. Arbustos escandentes, inflorescências paniculadas, axilares (Fig. 5 A), legumes samaróides (Fig. 5 B) 3.14 Dalbergia ecastaphyllum 35'. Arbustos eretos, inflorescências racemosas, terminais (Fig. 5 C), folículos (Fig. 5 D)

3.31 Zollernia glabra

34'. Folhas 2-42 folioladas.

36. Ramos glabros.

37. Folíolos falciformes (Fig. 5 E)

1.9 Hymenaea fariana

37'. Folíolos lanceolados (Fig. 5 F) ou elípticos (Fig. 5 G).

38. Pecíolos 12-26 mm compr.

39. Folíolos 25-38 mm compr., legumes.

40. Folíolos puberulentos, legumes moniliformes (Fig. $5 \mathrm{H}$ )

3.23 Sophora tomentosa

40'. Folíolos glabros, legumes 4-angulados 3.22 Sesbania virgata

39'. Folíolos 62-112 mm compr., folículos (Fig. 5 I)

38'. Pecíolos 25-75 mm compr.

41. Raque 21-57 $\mathrm{mm}$ compr.

42. Legumes, $4-5 \mathrm{~cm}$ larg.

3.11 Clitoria fairchildiana

42'. Sâmaras (Fig. 5 J) ou legumes samaróides (Fig. 5 K), 1,2-1,5 cm larg.

43. Pecíolos ca. 25 mm compr., legumes samaróides (Fig. $5 \mathrm{~K}$ ), $3 \mathrm{~cm}$ compr.

3.17 Leptolobium tenuifolium

43'. Pecíolos 40-45 mm compr., sâmaras (Fig. 5 J), 4,5 cm compr. 3.19 Machaerium lanceolatum

41'. Raque 60-140 $\mathrm{mm}$ compr.

44. Folíolos 50-80 mm compr., lanceolados, drupas (Fig. $5 \mathrm{~L}$ )

3.7 Andira nitida 44'. Folíolos 160-245 mm compr., estreitamente elípticos, folículos (Fig. 5 M) ..... 3.29 Swartzia apetala

36'. Ramos pubescentes a puberulentos.

45. Ramos inermes.

46. Pecíolos 4,5-15 mm compr., legumes.

47. Pecíolos 4,5-10 mm compr., folíolos com margem denteada

47'. Pecíolos 12-15 mm compr., folíolos com margem inteira

3.16 Exostyles venusta

46’. Pecíolos 20-40 mm compr., drupas

3.22 Sesbania virgata

45'. Ramos aculeados (Fig. $5 \mathrm{~N}$ )

3.6 Andira fraxinifolia

3.18 Machaerium hirtum

1'. Folhas bipinadas.

48. Ramos inermes.

49. Nectários foliares ausentes, folhas 36-46-folioluladas

1.8 Delonix regia

49'. Nectários foliares pateliformes, folhas 20-30-folioluladas

48'. Ramos armados.

50. Ervas, filetes róseos.

51. Folhas 1-2-pinadas, pecíolos 28-33 mm compr. (Fig. $5 \mathrm{~N}$ )

2.9 Mimosa pudica

51'. Folhas 7-10-pinadas, pecíolos ca. $8 \mathrm{~mm}$ compr. 2.8 Mimosa elliptica

50 '. Arbustos ou arvoretas, filetes brancos ou cremes.

52. Folhas 6-pinadas, foliólulos 17-44 mm compr.

2.7 Mimosa caesalpiniifolia

52'. Folhas 10-pinadas, foliólulos 7-9 mm compr. 2.6 Mimosa bimucronata 


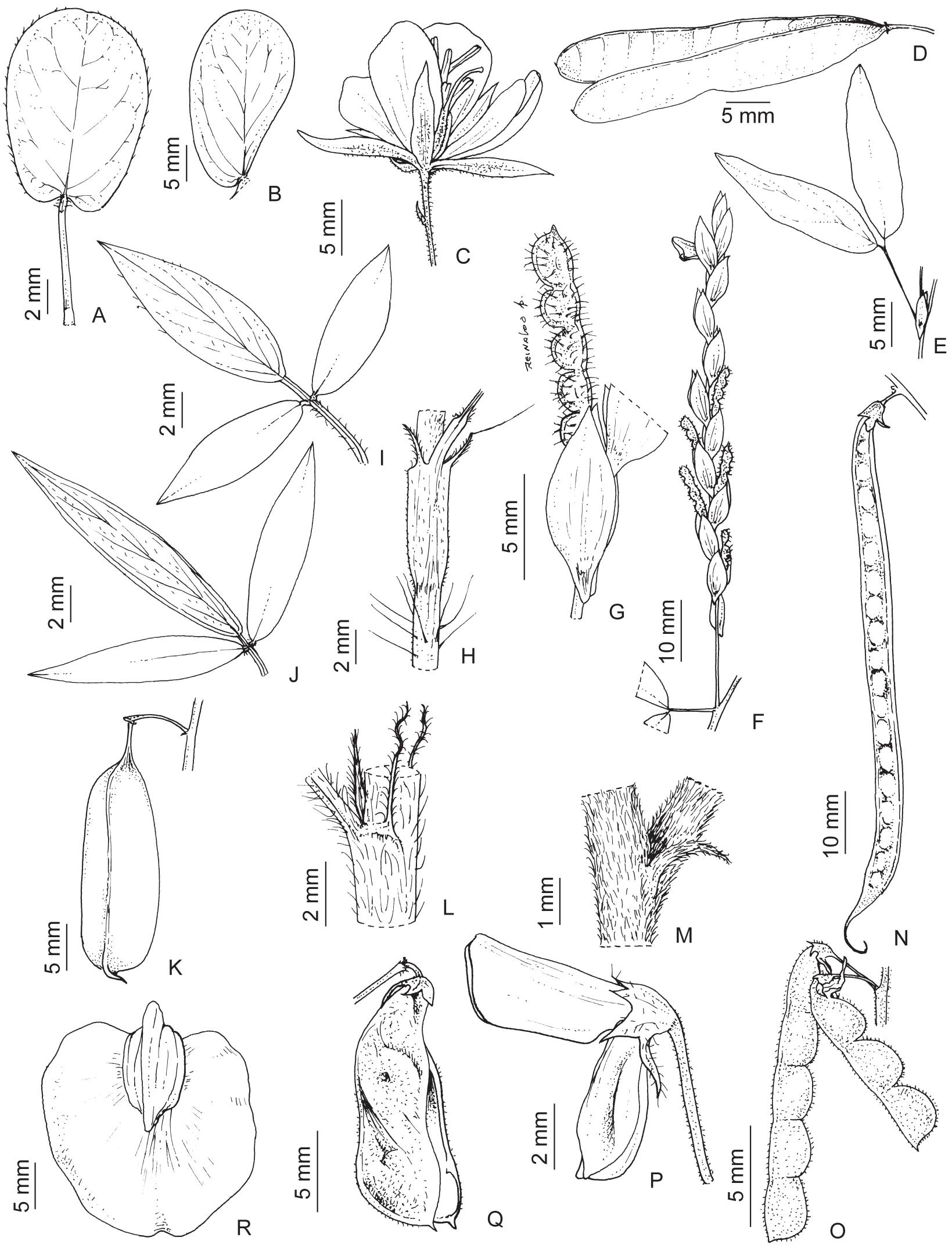

Figs. 3A-R. A. Alysicarpus vaginalis - Folha. B-D. Chamaecrista rotundifolia var. rotundifolia. B. Folíolo; C. Flor; D. Fruto. E-G. Zornia glabra. E. Folíolos; F. Inflorescência; G. Fruto. H, I. Stylosanthes gracilis. H. Estípulas; I. Folha; J. Stylosanthes scabra - Folha. K. Crotalaria maypurensis - Estípula. L, M. Crotalaria pallida. L. Fruto; M. Estípula. N. Ancistrotropis peduncularis - Fruto. O, P. Desmodium adscendens; O. Fruto; P. Flor. Q. Rhynchosia phaseoloides - Fruto. R. Centrosema virginianum Flor. 


\section{Caesalpinioideae}

1.1 Chamaecrista ensiformis (Vell.) H.S. Irwin \& Barneby, Mem. New York Bot. Gard. 35: 642. 1982. (Fig. 4J)

Arbustos a árvores, 2,5-5 m alt.; ramos glabros, inermes. Estípulas 14-26 × 6-12 mm, ovadas, livres, decíduas. Folhas paripinadas, 4-folioladas; pecíolos 51-79 $\mathrm{mm}$ compr., glabrescentes; raque foliar 28-51 mm compr., glabra; folíolos 78-123 × 40-69 mm, elípticos, base cuneada, ápice agudo, margem inteira, faces adaxial e abaxial glabras; nectários foliares entre os pares de folíolos, pateliformes. Inflorescências racemosas, 8-15-floras, caulifloras. Flores assimétricas, pentâmeras, não ressupinadas; cálice dialissépalo, pentâmero, 3-5 × 1,5-2 mm, sépalas lanceoladas, cremes a amarelas, tomentosas; corola dialipétala, 4 pétalas externas 14-16 × 6-7 mm, 1 vexilar interna $20 \times 8 \mathrm{~mm}$, elípticas, amarelas; estames 10 , livres, 5-5, $8 \mathrm{~mm}$ compr., homodínamos; filetes amarelos; anteras uniformes, 3,2-5 mm compr., poricidas, estaminódios ausentes; ovário ca. $5 \mathrm{~mm}$ compr., séssil, tomentoso; estilete ca. $11 \mathrm{~mm}$ compr., tomentoso. Legumes 9-7 × 0,9-1,5 $\mathrm{cm}$, glabros, elasticamente deiscentes. Sementes 13-14, largamente elípticas, 10-10,9 × 8,4-8,8 mm, marrons.

Espécie endêmica do Brasil ocorrendo nas regiões Norte (AM, PA, TO), Nordeste (AL, BA, CE, MA, PB, PE, PI, RN, SE), Centro-Oeste (GO, MT) e Sudeste (ES, MG, RJ, SP), nos Domínios Fitogeográficos da Amazônia, Caatinga, Mata Atlântica e Cerrado (BFG 2015, material suplementar). No PNMJ ocorre em Floresta Inundável e Floresta Não Inundável, em borda de estrada. Coletada com flores em janeiro, abril e julho com frutos em janeiro e outubro.

O gênero Chamaecrista possui como características as folhas paripinadas, inflorescência racemosa, flores amarelas, legumes elasticamente deiscentes (Rando 2009). No PNMJ, C. ensiformis difere-se das demais espécies do gênero Chamaecrista por possuir porte arbustivo ( $v s$. herbáceo a subarbustivo), pela presença de inflorescências (vs. flores solitárias), caulifloria e estípulas maiores (14-26 mm compr. vs. 3-12 nas demais espécies).

Material examinado: BRASIL, Espírito Santo, Vila Velha, Parque Natural Municipal de Jacarenema, 21.X.1987, O.J. Pereira et al. 1199 (VIES); 01.IV.2012, L.A. Silva (VIES); 25.VII.2012, L.A. Silva 228 (VIES); 10.I.2013, L.A. Silva 293 (VIES); 10.I.2013, L.A. Silva 294 (VIES); 10.I.2013, L.A. Silva 295 (VIES).

1.2 Chamaecrista flexuosa (L.) Greene, Pittonia 4: 27. 1899.

Ervas, $40-70 \mathrm{~cm}$ alt.; ramos glabros, inermes. Estípulas 6-8,6 $\times 1-2 \mathrm{~mm}$, lanceoladas, livres, persistentes. Folhas paripinadas, 76-88-folioladas; pecíolos 3,5-4 mm compr., puberulentos; raque foliar ca. $65 \mathrm{~mm}$ compr., esparsopubescente; folíolos 6-9 × 0,7-1,6 mm, elípticos, base oblíqua, ápice mucronado, margem inteira, faces adaxial e abaxial glabras; nectários foliares peciolares, caliciformes. Flores solitárias, axilares, assimétricas, pentâmeras, não ressupinadas; cálice dialissépalo, pentâmero, 6,69,5 × 2-4,8 mm, sépalas lanceoladas, vináceas, glabras; corola dialipétala, pentâmera, pétalas ca. $15 \times 10 \mathrm{~mm}$, elípticas, amarelas; estames 10 , livres, 5,7-6,8 mm compr., homodínamos; filetes amarelos; anteras uniformes, 5-6,1 mm compr., poricidas; estaminódios ausentes; ovário 8 $\mathrm{mm}$ compr., séssil, puberulento a tomentoso; estilete 2 mm compr., glabro. Legumes 4,1-5,9 $\times 4,6 \mathrm{~cm}$, glabros, elasticamente deiscentes. Sementes 8-16, retangulares, 2,5-3,7 × 1,7-2 mm, acinzentadas a oliváceas.

Espécie ocorrente no América do Sul: México, Cuba, Colômbia, Venezuela, Guiana, Suriname, Bolívia, Paraguai, Argentina e Brasil (Irwin \& Barneby 1982). No Brasil ocorre em todos os Estados brasileiros, nos Domínios Fitogeográficos da Amazônia, Caatinga, Cerrado, Mata Atlântica e Pantanal (BFG 2015, material suplementar). No PNMJ ocorre em vegetação Arbustiva Aberta Não Inundável. Coletada com flores e frutos em julho.

Diferencia-se das demais espécies de Chamaecrista presentes na área de estudo pelos ramos flexuosos e folíolos mais numerosos que nas demais espécies (76-88 vs. 2-40). Material examinado: BRASIL. ESPÍRITO SANTO, Vila Velha, Parque Natural Municipal de Jacarenema, 25.VII.2012, L.A. Silva 104 (VIES).

Material adicional examinado: BRASIL, ESPÍRITO SANTO, Vila Velha, Interlagos, 26.VII.2012, L.A. Silva 323 (VIES).

1.3 Chamaecrista nictitans subsp. patellaria (DC. ex Collad.) H.S. Irwin \& Barneby. Mem. New York Bot. Gard. 35: 814. 1982.

Ervas, ca. $1 \mathrm{~m}$ alt.; ramos puberulentos, inermes. Estípulas 4-12 × 0,7 mm, estreitamente elípticas, livres, persistentes. Folhas paripinadas, ca. 40-folioladas; pecíolos 2,8-4,6 mm compr., puberulentos; raque foliar ca. $40 \mathrm{~mm}$ compr., puberulentos; folíolos ca. $10 \times 2 \mathrm{~mm}$, oblongos, base oblíqua, ápice acuminado, margem inteira, faces adaxial e abaxial esparso-tomentosas; nectários foliares peciolares cupuliformes; Flores solitárias, axilares, zigomorfas, pentâmeras, não ressupinadas; cálice dialissépalo, pentâmero, ca. $3 \times 1,75 \mathrm{~mm}$, sépalas triangulares, verdes, tomentosas; corola dialipétala, pentâmera, 4 pétalas externas 3,6-4,3 × 1,6-3,9 mm, 1 vexilar interna 3,3 × 4,0 $\mathrm{mm}$, elípticas a obovadas, amarelas; estames 10 , livres, 1,7-2,5 mm compr. heterodínamos; anteras dimórficas, 0,6$1,9 \mathrm{~mm}$ compr., poricidas, estaminódios ausentes; ovário ca. 2,3 mm compr., séssil, tomentoso; estilete ca. $0,7 \mathrm{~mm}$ compr., glabro. Legumes 2,3-2,8 $\times 0,3 \mathrm{~cm}$, puberulentos, elasticamente deiscentes. Sementes 17-21, quadrangulares a retangulares, $2,4 \times 2 \mathrm{~mm}$, castanhas.

Chamaecrista. nictitans subsp. patellaria ocorre no Panamá, Colômbia, Venezuela, Paraguai, Brasil, Bolívia, México, Cuba, Jamaica, Belize, Costa Rica, Guiana 
Francesa, Guiana, Trinidad e Tobago, Peru, Índia, Sri Lanka, Indonésia, Fiji, Samoa e Havaí (Irwin \& Barneby 1982). No Brasil é encontrada em todos os Estados brasileiros, exceto no Rio Grande do Norte, nos Domínios Fitogeográficos da Amazônia, Caatinga, Cerrado, Mata Atlântica e Pantanal (BFG 2015, material suplementar). No PNMJ ocorre em vegetação Herbácea Não Inundável e Arbustiva Não Inundável, sendo este o seu primeiro registro para o PNMJ. Coletada com flores em junho, frutos em março.

O táxon possui como características diagnósticas o seguinte conjunto de caracteres: cerca de 40 folíolos e os nectários extraflorais sésseis, o que o diferencia de Chamaecrista nictitans subsp. disadena, que possui nectários estipitados e caliciformes.

Material examinado: BRASIL. ESPÍRITO SANTO, Vila Velha, Parque Natural Municipal de Jacarenema, 18.III.2012, L.A. Silva 125 (VIES); 18.III.2012, L.A. Silva 129 (VIES).

Material adicional examinado: BRASIL. ESPÍRITO SANTO, Vila Velha, Morro do Moreno, 28.VI.1984, Curso de Especialização em Biotaxonomia $s / n^{\circ}$ (VIES).

1.4 Chamaecrista nictitans subsp. disadena (Steud.) H.S. Irwin \& Barneby, Mem. New York Bot. Gard. 35: 825. 1982.

Ervas, ca. $1 \mathrm{~m}$ alt.; ramos puberulentos, inermes. Estípulas 4-12 × 0,7 mm, estreitamente elípticas, livres, persistentes. Folhas paripinadas, 20-36-folioladas; pecíolos 3,3-3,7 mm compr., puberulentos; raque foliar ca. $40 \mathrm{~mm}$ compr., esparso-puberulenta; folíolos 5,2-10,5 × 1,6$1,9 \mathrm{~mm}$, elípticos, base oblíqua, ápice mucronulado, margem inteira, faces adaxial e abaxial glabras; nectários foliares peciolares caliciformes. Flores solitárias, axilares, zigomorfas, pentâmeras, não ressupinadas, não papilionadas; cálice dialissépalo, pentâmero, 5-5,8 × 1,2$1,3 \mathrm{~mm}$, sépalas lanceoladas, verdes, tomentosas; corola dialipétala, pentâmera, 4 pétalas externas $6,4 \times 3 \mathrm{~mm}, 1$ vexilar interna $5,4 \times 2 \mathrm{~mm}$, elípticas, amarelas; estames 10, livres, 2,7-4,6 mm compr. heterodínamos; anteras uniformes, 2,3-4,3 mm compr., poricidas, estaminódios ausentes; ovário ca. $5 \mathrm{~mm}$ compr., séssil, tomentoso; estilete ca. $0,3 \mathrm{~mm}$ compr., glabro. Legumes 3,7-4,6 $\times 0,3-0,5 \mathrm{~mm}$, puberulentos, elasticamente deiscentes. Sementes 13-18, retangulares, 2,3 × 1,2-1,5 mm, castanhas.

Ocorre na América Central, Guiana, Panamá, Colômbia, Venezuela, Suriname, Paraguai, México e Brasil (Irwin \& Barneby 1982). No Brasil é encontrada nas regiões Norte (AC, AM, AP, PA, RR), Nordeste (AL, BA, CE, MA, PB, PE, PI, SE), Centro-Oeste (GO, MS), Sudeste (ES, MG, SP) e Sul (PR, RS, SC) habitando nos Domínios Fitogeográficos da Amazônia, Caatinga, Cerrado, Mata Atlântica e Pantanal (BFG 2015, material suplementar). No PNMJ ocorre em vegetação de Floresta Não Inundável, sendo este o seu primeiro registro de ocorrência para o parque. Coletada com flores em fevereiro, e frutos em fevereiro.
Chamaecrista nictitans subsp. disadena possui como característica diagnóstica o conjunto de carateres: folhas com 20-36 folíolos e nectários peciolares estipitados e caliciformes. Os caracteres que a diferenciam de $C$. nictitans subsp. patellaria foram discutidos anteriormente.

Material examinado: BRASIL. ESPÍRITO SANTO, Vila Velha, Parque Natural Municipal de Jacarenema, 7.II.2012, D.T. Iglesias 04 (VIES).

Material adicional examinado: BRASIL. ESPÍRITO SANTO, Vila Velha, Morro do Moreno, 1.VII.2012, L.A. Silva 222 (VIES).

1.5 Chamaecrista ramosa (Vogel) H.S. Irwin \& Barneby, Mem. New York Bot. Gard. 35: 884. 1982.

(Figs. 4D-F)

Ervas, ca. 50 alt., ramos pubescentes, inermes. Estípulas $3 \times 2 \mathrm{~mm}$, cordadas, livres, persistentes. Folhas paripinadas, 4-folioladas; pecíolos 1,5 mm compr., glabros; raque foliar ca. $0,1 \mathrm{~mm}$ compr., glabra; folíolos 8-10 × 4-5 mm, obovados, base cuneada, ápice arredondado, margem inteira, faces adaxial e abaxial glabras a pubescentes; nectários foliares ausentes. Flores solitárias, axilares, zigomorfas, pentâmeras, não ressupinadas, não papilionadas; cálice dialissépalo, pentâmero, 8-10 × 2,2-2,7 mm, sépalas verdes, glabras; corola dialipétala, pentâmera, 4 pétalas externas $12 \times$ $5 \mathrm{~mm}$, vexilar interna $8,6 \times 4 \mathrm{~mm}$, elípticas, amarelas; estames 10, livres, 6-7 mm compr., heterodínamos; anteras uniformes, 5,5-6,5 mm compr., poricidas; estaminódios ausentes; ovário $2,2 \mathrm{~mm}$ compr., séssil, tomentoso; estilete ca. $0,6 \mathrm{~mm}$ compr., glabro. Legumes 3,5-4,0 $\times 0,5-0,6$ $\mathrm{cm}$, pubescentes, elasticamente deiscentes. Sementes 6-14, obovadas, $3,3 \times 1,5 \mathrm{~mm}$, castanhas.

Chamaecrista ramosa ocorre na Bolívia, Venezuela, Guiana e Brasil (Irwin \& Barneby 1982), onde pode ser encontrada nas regiões Norte (AM, PA, RR, TO), Nordeste (AL, BA, CE, MA, PB, PE, PI, RN, SE), Centro-Oeste (DF, GO, MS, MT), Sudeste (ES, MG, RJ, SP) e Sul (PR). Habita os Domínios Fitogeográficos da Amazônia, Caatinga, Cerrado, Mata Atlântica e Pantanal (BFG 2015, material suplementar). No PNMJ ocorre em vegetação Arbustiva Aberta Não Inundável. Coletada com flores em fevereiro, abril, junho e frutos em abril e junho.

Junto com C. ensiformis, são as únicas espécies de Chamaecrista do PNMJ a apresentarem folhas 4-folioladas. No entanto, diferem no hábito (herbáceo vs. arbustivo em C. ensiformis), nos pecíolos (1,5 mm compr. vs. 52-79 $\mathrm{mm}$ compr.), raque foliar (ca. 0,1 mm compr. vs. 28-65 mm compr.) e por C. ramosa apresentar flores solitárias enquanto $C$. ensiformis apresenta flores em inflorescências. Material examinado: BRASIL, ESPÍRITO SANTO, Vila Velha, Parque Natural Municipal de Jacarenema, 7.II.2012, L.A. Silva 114 (VIES); 28.VI.2012, L.A. Silva 60 (VIES); 1.IV.2012, L.A. Silva 208 (VIES); 1.IV.2012, L.A. Silva 215 (VIES); 1.IV.2012, L.A. Silva 207 (VIES); 28.VI.2012, L.A. Silva 165 (VIES); 1.IV.2012, L.A. Silva 210 (VIES). 


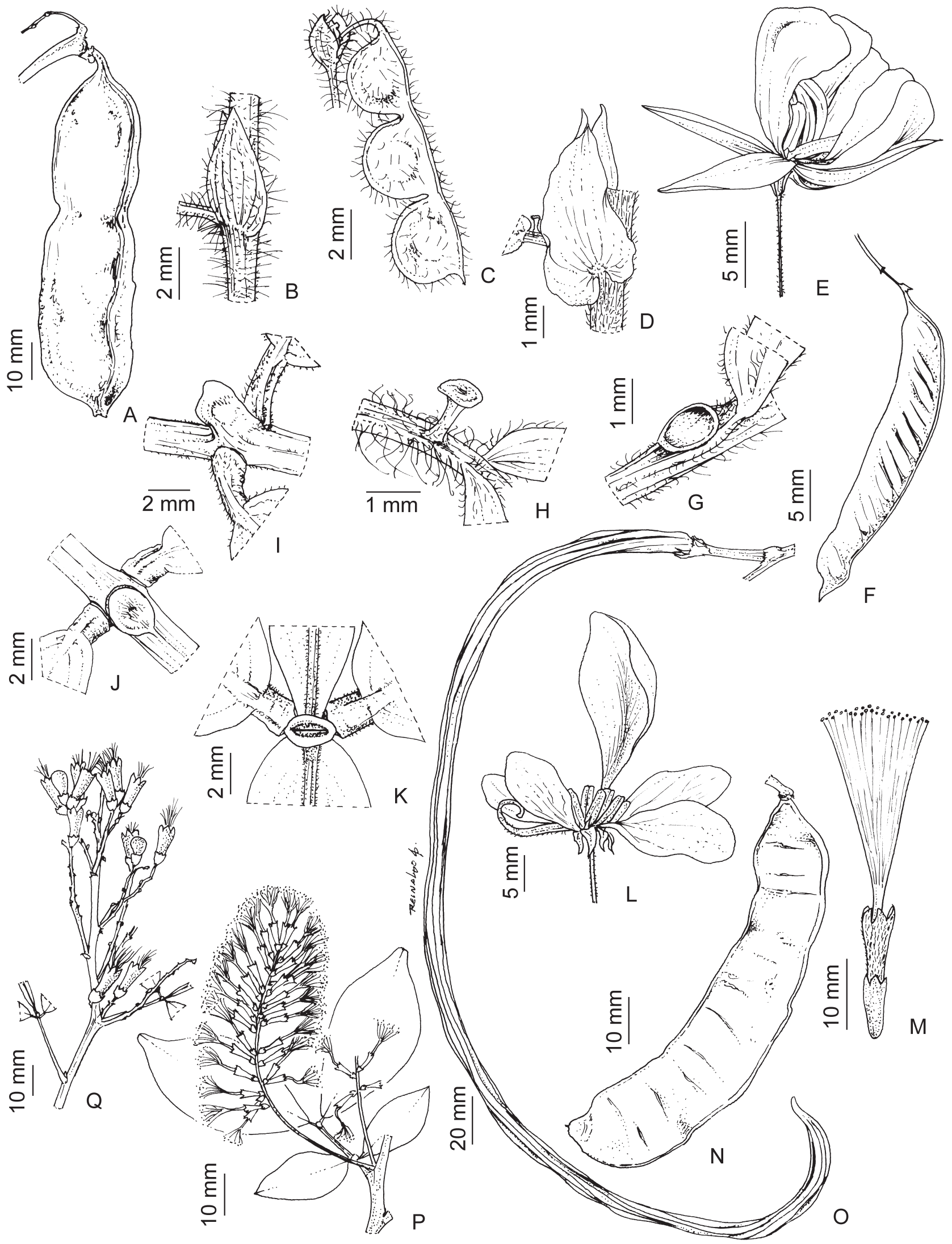

Figs. 4A-Q. A. Canavalia parviflora - Fruto. B, C. Aeschynomene brasiliana. B. Estípula; C. Fruto. D-F. Chamaecrista ramosa. D. Estípula; E. Flor; F. Fruto. G. Chamaecrista nictitans subsp. patellaria - Nectário foliar. H. Chamaecrista nictitans subsp. disadena - Nectário foliar. I. Senna appendiculata - Nectário foliar. J. Chamaecrista ensiformis - Nectário foliar. K. Inga edulis - Nectário foliar. L. Chamaecrista ensiformis - Flor. M. Inga edulis - Flor. N. Zygia latifolia var. glabrata - Fruto. O. Inga edulis - Fruto. P. Inga laurina- Inflorescência. Q. Inga subnuda - Inflorescência. 
1.6 Chamaecrista rotundifolia var. grandiflora (Benth.) H.S. Irwin \& Barneby, Mem. New York Bot. Gard. 35: 732. 1982.

Ervas, ca. $20 \mathrm{~cm}$ alt.; ramos puberulentos a tomentosos, inermes. Estípulas 4-6 $\times 2,2 \mathrm{~mm}$, cordadas a triangulares, livres, persistentes. Folhas paripinadas, 2-folioladas; pecíolos 3-5 mm compr., esparso- pubescentes; folíolos $25 \times 13-14 \mathrm{~mm}$, obovados, base oblíqua, ápice arredondado, margem inteira, face adaxial glabra, face abaxial esparsopuberulenta a pubescente; nectários foliares ausentes. Flores solitárias, axilares, zigomorfas, pentâmeras, não ressupinadas; cálice dialissépalo, pentâmero, 11-12 × 1,5-2 $\mathrm{mm}$, sépalas lanceoladas, verdes a castanhas, esparsotomentosas; corola dialipétala, pentâmera, 4 pétalas externas $13 \times 4 \mathrm{~mm}$, vexilar interna $11 \times 3,7 \mathrm{~mm}$, oblongas, amarelas; estames 5, livres, 5,5-13 mm compr., heterodínamos; anteras uniformes, 3,4-12,3 mm, poricidas; estaminódios 3-4; ovário ca. $15 \mathrm{~mm}$ compr., séssil, puberulento; estilete ca. 0,2 mm compr., glabro. Legumes 3,2-3,8 $\times$ 0,4-6 $\mathrm{cm}$, puberulentos a esparso-puberulentos, elasticamente deiscentes. Sementes 9-16, retangulares, 2,5-3 × 1,4-1,5 mm, castanhas.

Este táxon ocorre em Honduras, Colômbia, Equador, Venezuela, Guiana, Paraguai, Argentina, Bolívia e Brasil (Irwin \& Barneby 1982), onde pode ser encontrada nas regiões Nordeste (AL, BA, CE, PB, PE, PI, SE), CentroOeste (GO, MS, MT), Sudeste (ES, RJ, SP) e Sul (PR). Habita os Domínios Fitogeográficos da Caatinga, Cerrado e Mata Atlântica (BFG 2015, material suplementar). No PNMJ ocorre em Mangue Degradado e Área Antropizada, sendo este o primeiro registro de sua ocorrência para o Parque. Coletada com flores em fevereiro, março, agosto e frutos em março e outubro.

São características deste táxon as folhas bifolioladas, com os folíolos maiores que $1 \mathrm{~cm}$ de comprimento. Diferencia-se de Chamaecrista rotundifolia var. rotundifolia pelo tamanho da flor, que é menor na variedade típica: cálice (11-12 mm compr. vs. 2,2-2,5 mm compr.), pétalas (11-14 mm compr. $v s .3,4-3,8 \mathrm{~mm}$ compr.) e estames (5,5-13 mm compr. vs. ca. 2,7 mm compr.).

Material examinado: BRASIL, ESPÍRITO SANTO, Vila Velha, Parque Natural Municipal de Jacarenema, 16.II.2012, L.A. Silva $s / n^{\circ}$ (VIES); 1.III.2012, L.A. Silva 103 (VIES) 18.III.2012, L.A. Silva et al. 113 (VIES); 18.III.2012, L.A. Silva et al. 114 (VIES); 18.III.2012 L.A. Silva et al. 118 (VIES); 29.VIII.2012, L.A. Silva \& R.T. Valadares 241 (VIES).

1.7 Chamaecrista rotundifolia var. rotundifolia (Pers.) Greene, Mem. New York Bot. Gard., 35: 731. 1982.

(Figs. 3B-D)

Ervas, ca. $20 \mathrm{~cm}$ alt.; ramos tomentosos, inermes. Estípulas 7-9 × 1,5-2,5 mm, lanceoladas, livres, persistentes. Folhas paripinadas, 2-folioladas; pecíolos ca. $3,5 \mathrm{~mm}$ compr., tomentosos; folíolos 6,7-15 × 4-8 mm, elípticos, base oblíqua, ápice arredondado, margem inteira, faces adaxial e abaxial puberulentas; nectário foliar ausente. Flores solitárias, axilares, zigomorfas, pentâmeras, não ressupinadas; cálice dialissépalo, pentâmero, 2,2 × 2,5 $\mathrm{mm}$, sépalas lanceoladas, avermelhadas, pubescentes; corola diapétala, pentâmera, 4 pétalas externas ca. $3,4 \times 1 \mathrm{~mm}$, pétala vexilar interna $3,8 \times 1,5 \mathrm{~mm}$, elípticas, amarelas a rosadas; estames 5 , livres, ca. $2,7 \mathrm{~mm}$ compr., homodínamos; anteras uniformes, ca. 2,4 mm compr., poricidas; estaminódios 3; ovário ca. 2,6 mm compr., séssil, puberulento; estilete ca. $1.3 \mathrm{~mm}$ compr., glabro. Legumes não observados. Sementes não observadas.

Espécie ocorrente no México, Estados Unidos, Uruguai, Argentina, Venezuela, Colômbia, Costa Rica, Panamá, Bolívia e Cuba (Irwin \& Barneby 1982). No Brasil é encontrada nas regiões Norte (RO, TO), Nordeste (BA, CE, MA, PB, PE, PI, RN), Centro-Oeste (DF, GO, MS, MT), Sudeste (ES, MG, RJ, SP), Sul (PR, RS), em todos os biomas brasileiros (BFG 2015, material suplementar). No PNMJ ocorre em vegetação Arbustiva Aberta Não Inundável, sendo este o seu primeiro registro de ocorrência para o parque. Coletada com flores e frutos em outubro.

Chamaecrista rotundifolia var. rotundifolia é muito semelhante à variedade grandiflora, exceto pelo tamanho das flores, maiores nesta última. A relação entre estas duas variedades foi discutida anteriormente. Esta espécie se distingue das demais espécies do PNMJ pelas folhas 2-folioladas, com folíolos maiores de $1 \mathrm{~cm}$ de comprimento e flores pequenas, com cerca de $1 \mathrm{~cm}$ de comprimento.

Material examinado: BRASIL. ESPÍRITO SANTO, Vila Velha, Parque Natural Municipal de Jacarenema, 27.X.2012, L.A. Silva 291; 27.X.2012, L.A. Silva 292 (VIES).

\subsection{Delonix regia (Hook.) Raf., Fl. Tellur. 2: 92. 1837.}

Árvores, ca. $4 \mathrm{~m}$ alt.; ramos glabros, sulcados, inermes. Estípulas não observadas, decíduas. Folhas bipinadas, 23-pinadas, pecíolos 50-115 mm compr., glabros a puberulentos; raque foliar ca. $280 \mathrm{~mm}$ compr., glabra a esparso-puberulenta; foliólulos 36-46, 7-9 × 2,4-3 mm, elípticos, base oblíqua, ápice arredondado, margem inteira, puberulentos; nectários foliares ausentes. Inflorescências racemosas, 10-22-floras, terminais. Flores zigomorfas, pentâmeras, homomórficas; cálice dialissépalo, 25-30 × 30-40 mm, verde, glabro; corola diapétala; $50 \times 75 \mathrm{~mm}$, pétalas $42-70 \times 32 \mathrm{~mm}$, vermelhas; estames 10, livres, 36$46 \mathrm{~mm}$ compr., homodínamos, filetes $44 \mathrm{~mm}$ compr.; anteras uniformes, $4 \mathrm{~mm}$ compr., rimosas; estaminódios ausentes; ovário $10 \mathrm{~mm}$ compr., séssil, esparsamente pubescente; estiletes $35 \mathrm{~mm}$ compr., glabros. Legumes $40 \times 0,7-1 \mathrm{~cm}$, glabros, deiscentes. Sementes elípticas, ca. 26, $17 \times 7-8 \mathrm{~mm}$, castanhas.

Espécie nativa de Madagascar, cultivada em vários países tropicais, e nos estados da BA e PE. Delonix regia é considerada naturalizada no Brasil (Du Puy et al. 1995, BFG 2015, material suplementar). É conhecida 
pelo nome popular de flamboyant e muito utilizada na ornamentação urbana por conta de suas flores vistosas, grandes e vermelhas. Foi encontrada no PNMJ na borda da Rodovia do Sol, em uma região antropizada, sendo este o seu primeiro registro de ocorrência para o Parque. Coletada com flores em fevereiro e frutos em junho.

Material examinado: BRASIL. ESPÍRITO SANTO, Vila Velha, Parque Natural Municipal de Jacarenema, 28.VI.2012, L.A. Silva 156 (VIES); 03.II.2013, L.A. Silva $s / n^{o}$ (VIES).

1.9 Hymenaea fariana R.D. Ribeiro, D.B.O.S. Cardoso \& H.C. Lima, Syst. Bot., 40(1): 151. 2015.

(Fig. 5E)

Arbustos a arvoretas, 3-8 m alt.; ramos glabros, inermes. Estípulas não observadas, decíduas. Folhas paripinadas, 2-folioladas; pecíolos 9-16 mm compr., glabros; raque foliar ausente; folíolos 35-69 × 18-35 cm, falciformes, base oblíqua, ápice agudo, margem inteira, faces adaxial e abaxial glabras; nectários foliares ausentes. Inflorescências racemosas, 6-9-floras, terminais. Flores actinomorfas, pentâmeras, não ressupinadas; cálice dialissépalo, tetrâmero, $8,5 \times 8,5 \mathrm{~mm}$, sépalas triangulares ou arredondadas, verdes, glabras; corola dialipétala, pentâmera, pétalas $20 \times 10 \mathrm{~mm}$, oblongas, brancas; estames 10, livres, 28-36 mm compr., homodínamos; anteras uniformes, 1,9-2,9 mm compr., rimosas, estaminódios ausentes; ovário não observado. Legumes 4,6-8,2 × 2,8-3,6 cm, papilosos, indeiscentes. Sementes 4-7, elípticas, 1,6-2,1 × 5-9 mm, creme.

No Brasil ocorre nas regiões Nordeste (SE) e Sudeste (ES). Habita o Domínio Fitogeográfico da Mata Atlântica (BFG 2015, material suplementar). No PNMJ ocorre em vegetação Florestal Não Inundável. Coletada com frutos em junho, julho e agosto. Coleta das flores sem data registrada.

Hymenaea fariana pode ser diferenciada entre as demais espécies do PNMJ pelas folhas 2-folioladas com folíolos falciformes.

Material examinado: BRASIL, ESPÍRITO SANTO, Vila Velha, Parque Natural Municipal de Jacarenema, 30.VIII.2008, H. C. de Lima et al. 7004 (RB, imagem digital); 25.VII.2012, L.A. Silva 231 (VIES); 25.VII.2012, L.A. Silva 232 (VIES). 28.VI.2000, O.J. Pereira 6223 (VIES); s/d., K.S. Ribeiro $s / n^{\circ}$ (VIES).

1.10 Senna affinis (Benth.) H.S. Irwin \& Barneby, Mem. New York Bot. Gard. 35: 123. 1982.

Arbustos, ca 2,5 m alt.; ramos glabros, inermes. Estípulas não observadas, decíduas. Folhas paripinadas, 4-folioladas; pecíolos 30-33 mm compr., glabros; raque foliar 22-24 mm compr., glabra; folíolos 48-140 × 28-87 $\mathrm{mm}$, elípticos, base oblíqua, ápice agudo, margem inteira, faces adaxial e abaxial glabras; nectários foliares entre os pares de folíolos, claviformes. Flores não observadas. Legumes ca. $22 \times 0,9 \mathrm{~cm}$, glabros, deiscentes. Sementes 130 , reniformes a elípticas, 6-7 $\times 2-3 \mathrm{~mm}$, pretas.
A espécie ocorre na Bolívia e no Brasil, nas regiões Nordeste (BA) e Sudeste (ES, MG, RJ) habitando os Domínios Fitogeográficos do Cerrado e da Mata Atlântica (BFG 2015, material suplementar). No PNMJ ocorre em vegetação Arbustiva Fechada Não Inundável, sendo este o seu primeiro registro de ocorrência para o Parque. Coletada com frutos em junho.

Senna affinis apresenta fácil identificação pelo seguinte conjunto de caracteres: nectários foliares claviformes entre os pares de folíolos, ramos quadrangulares em corte transversal e frutos longos (ca. $22 \mathrm{~cm}$ compr.).

Material examinado: BRASIL, ESPÍRITO SANTO, Vila Velha, Parque Natural Municipal de Jacarenema, 12.VI.2013, L.A. Silva 359 (VIES); 12.VI.2013, L.A. Silva 360 (VIES).

1.11 Senna appendiculata (Vogel) Wiersema, Taxon 38(4): 652. 1989.

(Fig. 4I)

Arbustos, ca. $2 \mathrm{~m}$ alt.; ramos glabros a esparsopuberulentos, inermes. Estípulas ca. $2 \times 1 \mathrm{~cm}$, reniformes, livres, decíduas. Folhas paripinadas, 8-folioladas; pecíolos ca. $25 \mathrm{~mm}$ compr., esparso-puberulentos; raque foliar 65-80 mm compr., esparso-puberulenta; folíolos 40-70 × 30-51 mm, elípticos, base obtusa, ápice arredondado a obcordado, margem inteira, faces adaxial e abaxial glabras; nectários foliares presentes, entre os pares de folíolos, claviformes. Inflorescências racemosas, 7-13-floras, axilares. Flores assimétricas, pentâmeras, não ressupinadas; cálice dialissépalo, sépalas 17-20 × 8-10 mm, oblongas a elípticas, verdes a castanhas, glabras; corola dialipétala, pétalas 28-36 × 19-21 mm, elípticas, a oblongas, amarelas; estames 7, livres, 10-22 × 1,7-3 mm, heterodínamos; anteras dimórficas, 5-12 mm compr., poricidas, estaminódios 3; ovário ca. $27 \times 1 \mathrm{~mm}$, estipitado, puberulento; estilete 3-10- mm compr., glabro. Legumes 13-21 × 0,4 cm, glabros, deiscentes. Sementes 27-30, oblongas, 3-4 × 2,5 mm, castanhas a oliváceas.

Espécie de distribuição restrita ao território brasileiro, ocorrendo nas regiões Nordeste (AL, BA, PE, SE) e Sudeste (ES, SP). Habita os domínios fitogeográficos da Caatinga e da Mata Atlântica (BFG 2015, material suplementar). No PNMJ ocorre em vegetação Arbustiva Aberta Não Inundável. Coletada com flores em março, abril e junho e com frutos em junho.

Senna appendiculata possui como características diagnósticas: as estípulas reniformes, nectário foliares entre os pares de folíolos e flores com sete estames heterodínamos e anteras dimórficas.

Material examinado: BRASIL, ESPÍRITO SANTO: Parque Natural Municipal de Jacarenema: Vila Velha, 1.III.2012, L.A. Silva 102 (VIES); 28.VI.2012, L.A. Silva 161 (VIES); 28.VI.2012, L.A. Silva 162 (VIES); 28.VI.2012, L.A. Silva 163 (VIES); 28.VI.2012, L.A. Silva 164 (VIES); 1.IV.2012, L.A. Silva 217 (VIES). 


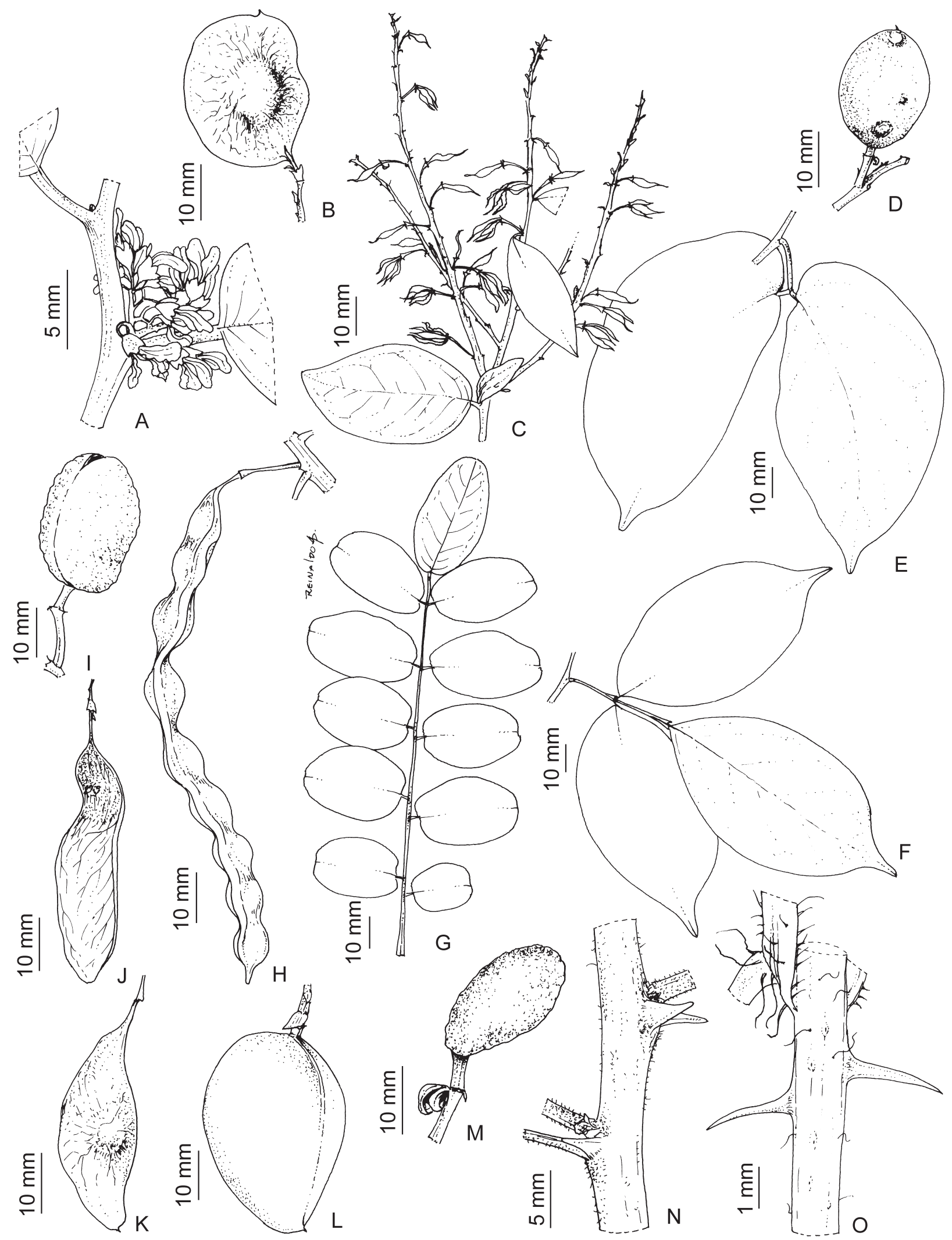

Figs. 5A-O. A. Dalbergia ecastaphyllum - Inflorescência; B-D. Zollernia glabra. B. Fruto; C. Inflorescência; D. Fruto. E. Hymenaea fariana Folha. F, I. Swartzia simplex. F. Folha; I. Fruto. G, H. Sophora tomentosa. G. Folha; H. Fruto. J. Machaerium lanceolatum - Fruto. K. Leptolobium tenuifolium - Fruto. L. Andira nitida - Fruto. M. Swartzia apetala - Fruto. N. Machaerium hirtum - Ramo armado. O. Mimosa pudica - Ramo aculeado. 


\section{Mimosoideae}

\subsection{Inga edulis Mart., Flora 20 (2, Beibl.): 113. 1837.} (Fig. 4K)

Arbustos, ca. 3,5 m alt.; ramos puberulentos, lenticelados, inermes. Estípulas 4-5 × 0,9 mm, triangulares, livres, decíduas. Folhas paripinadas, 4-6-folioladas; pecíolos ca. $35 \mathrm{~mm}$ compr., alados, puberulentos; raque foliar 83-63 mm compr.; puberulenta; folíolos 108-140 × 31-43 mm, elípticos, base cuneada, ápice agudo, margem inteira, faces adaxial e abaxial esparso-puberulentas; nectários foliares entre os pares de folíolos, cupuliformes transversalmente comprimidos. Inflorescências capituliformes, ca. 18 -floras, terminais. Flores actinomorfas, pentâmeras, não ressupinadas; cálice gamossépalo, pentâmero, $10 \times 2,4 \mathrm{~mm}$, tubuloso, verde-escuro, puberulento; corola gamopétala, ca. $17 \times 3 \mathrm{~mm}$, infundibuliforme, creme a verde; estames 35-40, monadelfos, 33-40 mm compr., homodínamos, tubo estaminal $15 \mathrm{~mm}$ compr.; filetes brancos; anteras uniformes, ca. $0,2 \mathrm{~mm}$ compr., rimosas; estaminódios ausentes; ovário ca. $45 \mathrm{~mm}$ compr., séssil, glabro; estilete $31-39 \mathrm{~mm}$ compr., glabro. Legumes nucoides 30-45 $\times 0,8 \mathrm{~cm}$, glabros, indeiscentes. Sementes 40-50, elípticas, 3,5 $\times 2$, pretas.

Espécie com distribuição Neotropical (Nunes et al. 2007). No Brasil ocorre nas regiões Norte (AC, AM, AP, PA, RO, RR), Nordeste (BA, PB, PE), Centro-Oeste (MT), Sudeste (ES, MG, RJ, SP) e Sul (PR, SC). Habita os Domínios Fitogeográficos da Amazônia, Caatinga, Cerrado e Mata Atlântica (BFG 2015, material suplementar). No PNMJ ocorre em Área Antropizada. Coletada com flores em janeiro e julho e frutos em janeiro.

Esta espécie teve apenas um indivíduo encontrado, localizado em um canteiro próximo ao posto do Polícia Rodoviária Federal, sendo provavelmente plantada. Difere das demais espécies pelos folíolos de 108-140 mm compr., nectários extraflorais cupuliformes transversalmente comprimidos e frutos com comprimento entre 30 e 45 $\mathrm{cm}$, maiores que os presentes nas demais espécies. Este é o primeiro registro de ocorrência desta espécie para o PNMJ. Material examinado: BRASIL, ESPÍRITO SANTO, Vila Velha, Parque Natural Municipal de Jacarenema, 25.VII.2012, L.A. Silva 233 (VIES); 10.I.2013, L.A. Silva $s / n^{\circ}$ (VIES).

2.2 Inga laurina (Sw.) Willd., Sp. P1., ed. 4 [Willdenow] 4 (2): 1018. 1806.

(Fig. 4P)

Arbustos, ca. 2,4 m alt.; ramos glabros, inermes. Estípulas ca. $5 \times 1 \mathrm{~mm}$, obovadas, livres, decíduas. Folhas paripinadas, 2-3-folioladas; pecíolos não alados, ca. 5,5 mm compr., puberulentos; raque foliar ca. $15 \mathrm{~mm}$ compr., esparso-puberulenta, marginada; folíolos 52-56 $\times 28 \mathrm{~mm}$, elípticos, base oblíqua a cuneada, ápice agudo, margem inteira, faces adaxial e abaxial glabras; nectários foliares entre os pares de folíolos, pateliformes. Inflorescências espiciformes, 50-60-floras, axilares. Flores actinomorfas, pentâmeras, não ressupinadas; cálice gamossépalo, ca. $4 \times 1,2 \mathrm{~mm}$, campanulado, verde, tomentoso; corola gamopétala, ca. $4,5 \times 2 \mathrm{~mm}$, tubulosa, verde; estames 18-22, monadelfos, 11-14 mm compr., homodínamos, tubo estaminal ca. $5 \mathrm{~mm}$ compr.; filetes brancos; anteras uniformes, ca. 0,2 mm compr., rimosas; estaminódios ausentes; ovário 7-9 mm compr., séssil, puberulento; estilete ca. $9 \mathrm{~mm}$ compr., glabro. Legumes nucoides 4,0-4,8 $\times 0,95$ $1,3 \mathrm{~cm}$, glabros, indeiscentes. Sementes 10-11, reniformes, 9-9,5 $\times 4 \mathrm{~mm}$, pretas.

Espécie com distribuição Neotropical (Pennington 1997). No Brasil ocorre nas regiões Norte (AC, AM, PA), Nordeste (BA, CE, MA, PB, PE), Centro-Oeste (DF, GO, MS, MT), Sudeste (ES, MG, RJ, SP) e Sul (PR), habitando os Domínios Fitogeográficos da Amazônia, Caatinga, Cerrado, Mata Atlântica (BFG 2015, material suplementar). No PNMJ ocorre em Florestal Não Inundável, Área Antropizada, Arbustiva Aberta Não Inundável. Coletada com flores em janeiro e frutos em janeiro.

Inga laurina diferencia-se das demais espécies de Inga ocorrentes no PMNJ por não possuir o pecíolo alado e pelo número de flores em sua inflorescência, que pode chegar a 60, enquanto as demais espécies deste gênero, ocorrentes no Parque, possuem no máximo 18 flores por inflorescência. Este é o primeiro registro de ocorrência desta espécie para o PNMJ.

Material examinado: BRASIL, ESPÍRITO SANTO, Parque Natural Municipal de Jacarenema, Vila Velha, 25.VII.2012, L.A. Silva 237 (VIES). 10.I.2013, L.A. Silva 296 (VIES).

2.3 Inga vera subsp. affinis (DC.) T.D. Penn., Gen. Inga: Bot. 716. 1997.

Arbustos a arvoretas, 6-8 m alt.; ramos puberulentos, inermes. Estípulas não observadas, decíduas. Folhas paripinadas, 8-10-folioladas; pecíolos 6-10 $\mathrm{mm}$ compr., pubescentes; raque foliar 42-58 $\mathrm{mm}$ compr., pubescente; folíolos 40-95 × 24-44 mm, elípticos, base arredondada, ápice agudo, margem inteira, faces adaxial e abaxial pubescentes; nectários entre os pares de folíolos, cupuliformes. Inflorescências racemosas, ca. 7-13-floras, axilares. Flores não observadas. Legumes nucoides $6,8-7,5 \times 1,8 \mathrm{~cm}$, pubescentes, indeiscentes. Sementes circulares, 2-5, 13-16 $\times 11 \mathrm{~mm}$, beges a marrons.

Táxon de distribuição nas Américas do Sul e Central (Pennington 1997). No Brasil ocorre nas regiões Norte (AC, AP, AM, PA, RO, RR, TO), Nordeste (BA, CE, MA, PB, PE, PI), Centro-Oeste (DF, GO, MT, MS), Sudeste (ES, MG, RJ, SP) e Sul (PR, SC, RS), habitando a Floresta Amazônica, Cerrado, Floresta Atlântica e Pantanal (BFG 2015, material suplementar). No PNMJ ocorre em Floresta Inundável e Mata Degradada. Coletada com botões florais em janeiro, frutos em janeiro e fevereiro.

Entre as demais espécies de Inga encontradas no PMNJ, difere pelos frutos lenhosos e distribuição restrita 
aos poucos pontos na margem do rio. A espécie possui o cálice persistente no fruto, as nervuras centrais dos folíolos puberulentas e a corola tomentosa.

Material examinado: BRASIL, ESPÍRITO SANTO, Vila Velha, Parque Natural Municipal de Jacarenema, 10.I.2013, L.A. Silva 297 (VIES), 16.II.2013, L.A.Silva 346 (VIES), 10.II.2013, L.A. Silva 337 (VIES).

\subsection{Inga subnuda Benth., London J. Bot. 4: 613. 1845.} (Fig. 4Q)

Arbustos, 2,5-3,5 m alt.; ramos glabros a puberulentos, inermes. Estípulas $4 \times 1,5 \mathrm{~mm}$, triangulares, livres, decíduas. Folhas paripinadas, 8-10-folioladas; pecíolos 8-16 mm compr., puberulentos; raque foliar 70-105 mm compr., puberulenta a esparso- puberulenta; folíolos 30-80 × 15-40 $\mathrm{mm}$, elípticos, base cuneada, ápice agudo a arredondado, margem inteira, face adaxial glabra a puberulenta, face abaxial glabra a pubescente; nectários foliares presentes, entre os pares de folíolos, cupuliformes. Inflorescências racemosas, ca. 12-floras, axilares. Flores actinomorfas, pentâmeras, homomórficas; cálice gamossépalo, pentâmero, ca. $3 \times 3,5 \mathrm{~mm}$, campanulado, marrom, tomentoso; corola gamopétala; ca. $16 \times 5 \mathrm{~mm}$, tubulosa, marrom; estames 36-42, monadelfos, ca, $40 \mathrm{~mm}$ compr., homodínamos, tubo estaminal ca. $17 \mathrm{~mm}$ compr.; filetes brancos; anteras uniformes, $1 \mathrm{~mm}$ compr., rimosas. Legumes nucoides $7,5 \times 2,5 \mathrm{~cm}$, puberulentos, indeiscentes. Sementes 4-12, obovadas, 12,8-14,2 $\times 9,5-10,8 \mathrm{~mm}$, marrons.

Endêmica do Brasil ocorrendo nas regiões Nordeste (BA, PB, PE), Sudeste (ES, MG, RJ, SP) e Sul (PR, SC), onde habita a Mata Atlântica (BFG 2015, material suplementar). No PNMJ ocorre na formação Arbustiva Fechada Não Inundável e Arbustiva Aberta Não Inundável.

Inga subnuda assemelha-se à Inga edulis, porém, possui os folíolos menores $(30-80 \times 15-40 \mathrm{~mm}$ vs. $108-140 \times$ $31-43 \mathrm{~mm})$ e frutos menores $(7,5 \times 2,5 \mathrm{~cm} v \mathrm{~s} .30-45 \times$ $0,8 \mathrm{~cm})$. Este é o primeiro registro de ocorrência desta espécie para o PNMJ.

Material examinado: BRASIL, ESPÍRITO SANTO, Vila Velha, Parque Natural Municipal de Jacarenema, 25.VII.2012, L.A. Silva 173b (VIES).

Material adicional examinado: BRASIL, ESPÍRITO SANTO, Vila Velha, Interlagos. 06.II.1996 O. Zambom 226 (VIES); Itapemirim, Itaoca. 10.V.1990, P.C. Vinha 899 (VIES); Linhares, Reserva Biológica de Comboios. 11.II.1995 I. Weiler Júnior 127 (VIES); Domingos Martins, 14.III.2001, O.J. Pereira 6881 (VIES).

2.5 Leucaena leucocephala (Lam.) de Wit, Taxon 10: 54. 1961.

Arbustos, 2-2,5 m alt.; ramos glabros, inermes. Estípulas ca. $2 \times 1 \mathrm{~mm}$, lanceoladas a triangulares, livres, decíduas. Folhas bipinadas, 16-pinadas; pecíolos 15-25 mm compr., glabros; raque foliar ca. $105 \mathrm{~mm}$ compr., glabra; foliólulos 20-30, 9-12 × 3-3,8 mm, elípticos, base oblíqua, ápice apiculado, margem inteira, faces adaxial e abaxial glabras; nectários foliares peciolares, pateliformes, elípticos, sésseis. Inflorescências capituliformes, ca. 135-floras, axilares. Flores actinomorfas, pentâmeras não ressupinadas; cálice gamossépalo, ca. 2,5 × 0,2 $\mathrm{mm}$, tubuloso, verde, glabro; corola gamopétala, ca. $4 \times 0,4 \mathrm{~mm}$, tubulosa, creme a amarela; estames 10, livres, 6-7 mm compr., homodínamos; filetes brancos; anteras uniformes, ca. $0,7 \mathrm{~mm}$ compr., rimosas; estaminódios ausentes; ovário ca. $10 \mathrm{~mm}$ compr., séssil, glabro; estilete ca. 4,4 mm compr., glabro. Legumes 17-22 × 1,8-2,1 cm, glabros, deiscentes. Sementes 12-17, elípticas, $9 \times 6,6 \mathrm{~mm}$, marrons.

Espécie com distribuição pantropical (Hughes 1998). No Brasil ocorre nas regiões Norte (AC, AM), Nordeste (BA, CE, PB, PE), Centro-Oeste (DF, MT), Sudeste (ES, MG, RJ, $\mathrm{SP}$ ) e Sul (PR), habitando a Amazônia, Caatinga, Cerrado e Mata Atlântica (BFG 2015, material suplementar). No PNMJ ocorre na formação Arbustiva Aberta Inundável, Área Antropizada e Florestal Não Inundável. Coletada com flores em março e frutos de março e junho.

Difencia-se das demais espécies do PNMJ por possuir inflorescência capituliforme com filetes brancos, frutos do tipo legume e ocorrência praticamente restrita aos ambientes não preservados. Possui alto potencial invasor de ambientes. É considerada naturalizada no Brasil.

Material examinado: BRASIL, ESPÍRITO SANTO: Parque Natural Municipal de Jacarenema: Vila Velha, 1.III.2012. L.A. Silva 105 (VIES), 28.VI.2012, L.A. Silva 170 (VIES).

2.6 Mimosa bimucronata (DC.) Kuntze, Revis. Gen. Pl. 1: 198. 1891.

Arbustos a arvoretas, 2-7 $\mathrm{m}$ alt.; ramos puberulentos, armados. Estípulas 2,8-3 × $7 \mathrm{~mm}$, triangulares, livres, persistentes. Folhas bipinadas, 10-pinadas; pecíolos ca. 10 $\mathrm{mm}$ compr., puberulentos; raque foliar ca. $30 \mathrm{~mm}$ compr., pubescente; foliólulos 44-48, 7-9 × 1-1,5 mm, elípticos, base oblíqua, ápice agudo a arredondado, margem inteira, faces adaxial e abaxial glabras; nectários foliares ausentes. Inflorescências capituliformes, 22-26-floras, axilares. Flores actinomorfas, pentâmeras, não ressupinadas; cálice gamossépalo, pentâmero, ca. 0,7 ×0,4 mm, campanulado, creme, glabro; corola gamopétala, ca. $2 \times$ $1 \mathrm{~mm}$, subinfundibuliforme, creme; estames 8 , livres, ca. $7 \mathrm{~mm}$ compr., homodínamos; filetes brancos; anteras uniformes, ca. $0,1 \mathrm{~mm}$, rimosas, estaminódios ausentes; ovário ca. $7 \mathrm{~mm}$ compr., estipitado, glabro; estilete $7 \mathrm{~mm}$ compr., glabro. Craspédios 3,1 $\times 0,7-0,8 \mathrm{~cm}$, glabros, deiscentes. Sementes 3-7, circulares, $3 \times 2 \mathrm{~mm}$, oliváceas.

Espécie ocorrente no Paraguai, Argentina, Brasil, cultivada na Guiana e naturalizada na Jamaica, Singapura, China e África tropical (Barneby 1991). No Brasil ocorre nas regiões Norte (AC, AM), Nordeste (BA, CE, PB, $\mathrm{PE})$, Centro-Oeste (DF, MT), Sudeste (ES, MG, RJ, SP) e Sul (PR), nos Domínios Fitogeográficos da Amazônia, Caatinga, Cerrado e Mata Atlântica (Silva \& Tozzi 2011; 
BFG 2015, material suplementar). No PNMJ ocorre em Floresta Inundável, Mata Degradada e Arbustiva Fechada Não Inundável. Coletada com flores em fevereiro, maio, outubro e frutos em maio e junho.

As características diagnósticas da espécie para o PNMJ são o hábito arbustivo a arbóreo, o fruto do tipo craspédio, a inflorescência capituliforme e as flores com filetes brancos. Este é o primeiro registro de ocorrência desta espécie para o PNMJ.

Material examinado: BRASIL, ESPÍRITO SANTO, Vila Velha, Parque Natural Municipal de Jacarenema, 30.V.2012, L.A. Silva 171 (VIES); 28.VI.2012, L.A. Silva 157 (VIES); 27.X.2012, L.A. Silva 279 (VIES); 16.II.2013, L.A. Silva 345 (VIES).

2.7 Mimosa caesalpiniifolia Benth., J. Bot. (Hooker) 4 (31): 392. 1841.

Arbustos, ca. $3 \mathrm{~m}$ alt.; ramos glabros a puberulentos, armados. Estípulas 4-7,5 ×0,4 mm, estreitamente triangulares a lanceoladas, livres, persistentes. Folhas bipinadas, 6-pinadas; pecíolos 8-20 mm compr., pubescentes; raque foliar 40-56 mm compr., glabra; foliólulos 4-8, 17-44 × 9-21 mm, ovados a obovados, assimétricos, base oblíqua, ápice agudo, margem inteira, glabros; nectários foliares ausentes. Inflorescências espiciformes, ca. 144-floras, terminais. Flores actinomorfas, trímeras, não ressupinadas; cálice gamossépalo, ca. $0,5 \times 0,5 \mathrm{~mm}$, campanulado, branco a bege, esparso-puberulento; corola gamopétala, ca. $2 \times 1$ $\mathrm{mm}$, campanulada, bege a branca; estames 7, livres, 6-7 mm compr., homodínamos; filetes brancos; anteras uniformes, ca. 0,4 mm compr., rimosas; estaminódios ausentes; ovário não observado. Frutos não observados.

Espécie endêmica do Brasil ocorrendo nas regiões Norte (AM, PA, RO), Nordeste (AL, BA, CE, MA, PB, PE, PI, RN), Centro-Oeste (DF, GO,MS), Sudeste (ES, MG, RJ, SP), e Sul (PR, SC), nos Domínios Fitogeográficos da Amazônia, Caatinga, Cerrado e Mata Atlântica (BFG 2015, material suplementar). No PNMJ ocorre em Área antropizada. Coletada com flores em agosto.

Esta espécie pode ser identificada pelo número de folíolulos, que variam de 4 a 8 e pela inflorescência espiciforme, com estames de filetes brancos. Este é o primeiro registro de ocorrência desta espécie para o PNMJ. Material examinado: BRASIL, ESPÍRITO SANTO, Vila Velha, Parque Natural Municipal de Jacarenema, 29.VIII.2012, L.A. Silva $246 B$ (VIES).

2.8 Mimosa elliptica Benth., J. Bot. (Hooker) 4 (32): 400.1842 .

Ervas, 1,2 m de alt.; ramos esparsamente pubescentes, armados. Estípulas, $5 \times 1 \mathrm{~mm}$, lanceoladas, livres, persistentes; folhas bipinadas, 7-10 pinas, 30-52-folioladas; pecíolos 7-8 mm compr., pubescentes; raque foliar 35-45 mm compr., pubescente a tomentosa; foliólulos 6-7 × $1 \mathrm{~mm}$, elípticos, base assimétrica, ápice mucronulado, margem inteira, faces adaxial e abaxial glabras a puberulentas, pubescente na margem; nectário foliar ausente. Inflorescências capituliformes, ca. 39-floras, terminais. Flores actinomorfas, tetrâmeras, homomórficas, flores não ressupinadas; cálice gamossépalo, 0,45 ×0,25 mm, campanulado, verde, glabro; corola gamopétala; rosa, $1,4 \times 1,4 \mathrm{~mm}$, tubular; estames 6 , livres, 7,8 mm compr., homodínamos; filetes brancos; anteras uniformes, 0,2 mm compr., rimosas; estaminódios ausentes; ovário $1 \mathrm{~mm}$ compr., estipitado, esparsamente puberulento; estilete 8 mm compr., glabro. Craspédios não observados.

Espécie ocorrente no Brasil e na Argentina. No Brasil ocorre nas regiões Nordeste (BA) e Sudeste (RJ, SP), nos Domínios Fitogeográficos da Mata Atlântica (BFG 2015, material suplementar). No PNMJ ocorre em área aberta não inundável. Coletada com flores em fevereiro e outubro.

Mimosa elliptica possui espinhos nos ramos, de 6-7 mm compr., pecíolos de 7-8 mm compr. Difere de Mimosa pudica por possuir espinhos menores, de cerca de $2 \mathrm{~mm}$ compr., menor número de pinas (4vs. 7-10) e pecíolos maiores, com 28-33 mm de comprimento (vs. $8 \mathrm{~mm}$ compr.). Este é o primeiro registro de ocorrência desta espécie para o PNMJ.

Material examinado: BRASIL. ESPÍRITO SANTO: Parque Natural Municipal de Jacarenema: Vila Velha, 27.X.2012, L.A. Silva 285 (VIES); 17.II.2014, L.A. Silva 366 (VIES); 21.II.2014, L.A. Silva 369 (VIES).

\subsection{Mimosa pudica L., Sp. P1. 1: 518. 1753.}

(Fig. 5O)

Ervas prostradas; ramos esparso-tomentosos a glabros, armados. Estípulas 5-6 × 2 mm compr., triangulares, livres, persistentes. Folhas bipinadas, 1-2-pinadas; pecíolos 28-33 mm compr., esparso-tomentosos a glabros; raque foliar 1-2 mm compr., esparso-tomentosa; foliólulos 28,9 × 2,4 mm, elípticos, base oblíqua, ápice agudo a arredondado, margem inteira, face adaxial glabra, face abaxial de esparso-tomentosa a esparso-puberulenta; nectários foliares ausentes. Inflorescências capituliformes, ca. 40-floras, axilares ou terminais. Flores actinomorfas, tetrâmeras, não ressupinadas; cálice gamossépalo, 0,2$0,4 \times 0,2 \mathrm{~mm}$, campanulado, castanho, glabro; corola gamopétala, castanha, 1,5-2,5 × 1,2 mm, infundibuliforme a campanulada; estames 4 , monadelfos, 5-7 $\times 0,2 \mathrm{~mm}$, homodínamos, tubo estaminal 2-3 mm compr.; filetes róseos; filetes brancos; anteras uniformes, ca. 0,5 $\mathrm{mm}$, rimosas; estaminódios ausentes; ovário 5-7 mm compr., glabro; estilete, 5-7 mm compr., séssil, glabro. Craspédios 1-1,7 × 0,4-0,5 cm, glabros, deiscentes. Sementes 1-2, circulares, 2,6 $\times 2,6 \mathrm{~mm}$, pretas.

Espécie ocorrente nas Américas do Norte e do Sul, África e Ásia (Barneby 1991). No Brasil é ocorrente nas regiões Norte (AM, PA, RO, RR), Nordeste (BA), CentroOeste (DF, MS, MT), Sudeste (ES, MG, RJ, SP) e Sul (PR, RS, SC). Habita a Amazônia, Caatinga, Cerrado e Mata Atlântica (BFG 2015, material suplementar). No 
PNMJ ocorre em Área antropizada. Coletada com flores e frutos em maio.

Assemelha-se à Mimosa elliptica. Os carateres que diferenciam estas espécies foram discutidos anteriormente. Este é o primeiro registro de ocorrência desta espécie para o PNMJ.

Material examinado: BRASIL. ESPÍRITO SANTO: Parque Natural Municipal de Jacarenema: Vila Velha, 30.V.2012, L.A. Silva 176 (VIES).

2.10 Zygia latifolia var. glabrata (Mart.) Barneby \& J.W. Grimes, Civ. Nat. Hist. Jamaica 279. 1756.

(Fig. 4N)

Arbustos, ca. de $3 \mathrm{~m}$ de alt; ramos pubescentes, inermes. Estípulas 0,8-1,2 ×0,2 $\mathrm{mm}$, triangulares, persistentes. Folhas paripinadas, 4-6-folioladas; pecíolos 2,4-3,3 mm compr., esparso-puberulentos; raque foliar 23-30 mm compr., puberulenta a esparso-puberulenta; folíolos 38-50 × $20 \mathrm{~mm}$, elípticos, base oblíqua, ápice de mucronulado a arredondado, margem inteira, faces adaxial e abaxial glabras; nectários entre os pares de folíolos e no pecíolo, pateliformes, sésseis. Inflorescências racemosas, capituliformes, 6-8-floras, axilares. Flores actinomorfas, pentâmeras, não ressupinadas; cálice gamossépalo, 4-5 $\times$ 1,8-2 mm, campanulado, castanho, glabro; corola não observada; estames 20-25, livres, 38-60 mm, homodínamos, tubo estaminal 7-8 mm compr.; filetes brancos; anteras uniformes, $0,1 \mathrm{~mm}$ compr., rimosas; estaminódios ausentes; ovário 1,45 mm compr., séssil, pubescente; estilete 7 compr., glabro. Legumes nucoides $8,5 \times 1,65 \mathrm{~cm}$, glabros, indeiscentes.

Táxon endêmico do Brasil, distribuído pelas regiões Nordeste (BA, PE), Sudeste (ES, MG, RJ, SP) e Sul (PR) nos Domínios Fitogeográficos da Amazônia, Cerrado e Mata Atlântica. (BFG 2015, material suplementar). No PNMJ ocorre na formação Arbustiva Aberta Inundável. Coletada com flores em fevereiro.

Zygia latifolia var. glabrata possui o pecíolo alado, no formato oblonceolado.

Material examinado: BRASIL, ESPÍRITO SANTO, Vila Velha, Parque Natural Municipal de Jacarenema, 07.II.2012, D.T. Iglesias 07 (VIES).

\section{Papilionoideae}

\subsection{Aeschynomene americana L. Sp. Pl. 2: 713. 1753.}

Ervas, ca. $60 \mathrm{~cm}$ alt.; ramos híspidos, inermes. Estípulas 8-12 × 1-2 mm compr., peltadas, livres, persistentes. Folhas paripinadas, $46-52$ folioladas, pecíolos $2-3 \mathrm{~mm}$ compr., tomentosos; raque foliar $34-35 \mathrm{~mm}$ compr., híspida a glabra; folíolos 5-9 × 1-2 mm, elípticos, base oblíqua arredondada, ápice mucronado a arrendondado, margem inteira, faces adaxial e abaxial glabras; nectários foliares ausentes. Inflorescências e flores não observadas. Lomentos 6-8-articulados, ca. 3,0-3,5 ×0,4 cm, glabros, indeiscentes. Sementes 1 por artículo, reniformes, $1,0-1,5 \times$ $1,0 \mathrm{~mm}$, marrons.

Espécie ocorrente dos Estados Unidos até a Argentina (Souza et al. 2012). No Brasil é encontrada nas regiões Norte (AC, AM, PA, RO, RR, TO) Nordeste (BA, CE, MA, PB, PE, PI, RN) Centro-Oeste (DF, GO, MS, MT), Sudeste (ES, MG, RJ, SP) e Sul (PR, SC) na Amazônia, Caatinga, Cerrado, Mata Atlântica e Pantanal (BFG 2015, material suplementar). No PNMJ ocorre na formação Florestal Não Inundável. Coletada com flores e frutos em maio.

Difere das demais espécies de Aeschynomene do PNMJ por ser a única que possui estípulas peltadas. Além disso, é a espécie que possui as maiores estítulas $(8-12 \mathrm{~mm}$ de compr. vs. 3,5 $\mathrm{mm}$ em A. brasiliana vs. $4 \mathrm{~mm}$ em $A$. falcata), o maior número de folíolos (46-52 vs. 11-13 em A. brasiliana vs. $10 \mathrm{em}$ A. falcata), o menor comprimento da raque foliar (3,4-3,5 $\mathrm{mm}$ vs. $15 \mathrm{~mm}$ em A. brasiliana vs. $16 \mathrm{~mm}$ em A. falcata) e os menores folíolos (5-9 × 1-2 $\mathrm{mm} v s .10 \times 5 \mathrm{~mm}$ em $A$. brasiliana vs. $11 \times 5-6 \mathrm{~mm}$ em A. falcata). Este é o primeiro registro de ocorrência desta espécie para o PNMJ.

Material examinado: BRASIL. ESPÍRITO SANTO, Vila Velha, Parque Natural Municipal de Jacarenema, 30.V.2012, L.A. Silva 174 (VIES).

3.2 Aeschynomene brasiliana (Poir.) DC., Prodr. 2: 322. 1825.

\section{(Fig. 4A)}

Ervas a subarbustos, ca. $1 \mathrm{~m}$ alt.; ramos tomentosos, glandulosos, inermes. Estípulas ca. 3,5 × $2 \mathrm{~mm}$ compr., triangulares, livres, persistentes. Folhas imparipinadas, 7-13 folioladas, pecíolos ca. $8 \mathrm{~mm}$ compr., tomentosos, glandulosos; raque foliar ca. $15 \mathrm{~mm}$ compr., pubescente a tomentosa; folíolos ca. $10 \times 5 \mathrm{~mm}$, elípticos, base oblíqua arredondada, ápice mucronado a arrendondado, margem inteira, faces adaxial e abaxial glabras; nectários foliares ausentes. Inflorescências e flores não observadas. Lomentos 1-2-articulados, ca. $0,7 \times 0,2 \mathrm{~cm}$, pubescentes, tardiamente deiscentes. Sementes 1 por artículo, reniformes, ca. 1,6 $\times$ $1,0 \mathrm{~mm}$, marrom-escuras.

Espécie ocorrente na Bolívia, Colômbia, Costa Rica, Cuba, El Salvador, Guatemala, Guiana Francesa, Nicarágua, Panamá, Peru, Suriname, Trinidad e Tobago Venezuela (Fernandes 1996). No Brasil é encontrada nas regiões Norte (AM, AP, PA, RO, RR), Nordeste (BA, MA, PB, PE, PI), Centro-Oeste (DF, GO, MS, MT) e Sudeste (MG, SP), onde ocorre nos Domínios Fitogeográficos da Amazônia, Caatinga, Cerrado, Mata Atlântica e Pantanal (BFG 2015, material suplementar). No PNMJ ocorre na formação Arbustiva Fechada Inundável. Coletada com frutos em março.

A relação entre as espécies do gênero foi discutida anteriormente. Este é o primeiro registro de ocorrência desta espécie para o PNMJ.

Material examinado: BRASIL. ESPÍRITO SANTO, Vila Velha, Parque Natural Municipal de Jacarenema, 18.III.2012, L.A. Silva 115 (VIES); 18.III.2012, L.A. Silva 122 (VIES); 
3.3 Aeschynomene falcata (Poir.) DC., Prodr. 2: 322. 1825.

Ervas, $60 \mathrm{~cm}$ alt.; ramos glabros a pubescentes no ápice, inermes. Estípulas $4 \times 1 \mathrm{~mm}$ compr., triangulares, livres, persistentes. Folhas paripinadas, 10 folioladas, pecíolos ca. 2-3 mm compr., pubescentes; raque foliar ca.16 mm compr., pubescente; folíolos $11 \times 5-6 \mathrm{~mm}$, oblongos, base oblíqua, ápice mucronado, margem inteira, faces adaxial e abaxial esparsamente pubescentes a pubescentes; nectários foliares ausentes. Inflorescências e flores não observadas. Lomentos 6 -articulados, 3,8 $\times$ $0,2 \mathrm{~cm}$, pubescentes. Sementes 1 por artículo, ovadas, $1,5 \times 1,0 \mathrm{~mm}$, marrom-claras.

Espécie ocorrente na Argentina, Bolívia, Paraguai, Brasil e Colômbia (Rudd 1955). No Brasil ocorre nas regiões Nordeste (AL, BA), Centro-Oeste (DF, GO, MS, MT), Sudeste (ES, MG, RJ, SP) e Sul (PR, RS, SC), nos Domínios Fitogeográficos da Caatinga, Cerrado, Mata Atlântica e Pampa (BFG 2015, material suplementar). No PNMJ ocorre em Mata Degradada. Coletada com frutos em março e agosto.

A comparação entre as espécies do gênero já foi realizada anteriormente. Este é o primeiro registro de ocorrência desta espécie para o PNMJ.

Material examinado: BRASIL. ESPÍRITO SANTO, Vila Velha, Parque Natural Municipal de Jacarenema, 18.III.2012, L.A. Silva 127 (VIES).

3.4 Alysicarpus vaginalis (L.) DC., Prodr. 2: 353. 1825. (Fig. 3A)

Ervas, ca. $20 \mathrm{~cm}$ alt.; ramos glabrescentes a puberulentos, inermes. Estípulas ca. 5,7 × 1,4 mm, triangulares, livres, persistentes. Folhas 1-folioladas; pecíolos ca. 9,7 mm compr., glabros a puberulentos; folíolos 8-15 × 7-12 mm, elípticos a circulares, base retusa, ápice arredondado, margem inteira, faces adaxial e abaxial esparso-puberulentas; nectários foliares ausentes. Inflorescências racemosas, ca. 20 -floras, terminais. Flores não observadas. Lomentos 5-6 artículos, ca. $1,9 \times 0,2 \mathrm{~cm}$, glabros, indeiscentes. Sementes 1 por artículo, reniformes, $1,7 \times 1 \mathrm{~mm}$, beges.

Espécie com distribuição original no Velho Mundo (Pedley 2001) e introduzida no Novo Mundo (TorresColin et al. 2011). No Brasil ocorre nas regiões Norte (TO), Nordeste (PI), Centro-Oeste (GO, MS, MT), Sudeste (SP) e Sul (PR), habitando os Domínios Fitogeográficos do Cerrado e Pantanal (BFG 2015, material suplementar). No PNMJ ocorre em Manguezal Degradado e Área Antropizada. Coletada com flores e frutos em março.

As características exclusivas desta espécie são as estípulas beges, paleáceas e bem desenvolvidas e os frutos articulados do tipo lomento. Este é o primeiro registro de ocorrência desta espécie para o PNMJ.

Material examinado: BRASIL, ESPÍRITO SANTO, Vila Velha, Parque Natural Municipal de Jacarenema, 01.III.2012, L.A. Silva 354 (VIES).
3.5 Ancistrotropis peduncularis (Fawc. \& Rendle) A. Delgado, Amer. J. Bot.98(10): 1704. 2011.

(Fig. 3N)

Trepadeiras; ramos glabros, sulcados, inermes. Estípulas 2-3 $\times 1-2 \mathrm{~mm}$, triangulares, livres, persistentes; Folhas imparipinadas, 3-folioladas; Pecíolos ca. $40 \mathrm{~mm}$ compr., pubescentes; raque foliar ca. $11 \mathrm{~mm}$ compr., esparsamente puberulenta; folíolos 35-45 × 30-45 mm, deltados, base oblíqua, cuneada ou truncada, ápice agudo, margem inteira, faces adaxial e abaxial glabras; nectário foliar ausente. Inflorescência racemo, ca. 4-10-floras, terminal. Flores papilionadas, assimétricas, pentâmeras, não ressupinadas; cálice gamossépalo, ca. $5 \times 4 \mathrm{~mm}$, campanulado, verde, glabro; corola dialipétala, lilás, ca. $13 \times 10 \mathrm{~mm}$, vexilo ca. $12 \times 11 \mathrm{~mm}$, alas ca. $15 \times 5 \mathrm{~mm}$, carenas ca. $16 \times 5$ $\mathrm{mm}$, espiraladas; estames 10 , diadelfos, $16-18 \mathrm{~mm}$ compr., homodínamos, tubo estaminal 15-17 mm compr.; anteras uniformes, $1 \mathrm{~mm}$ compr., rimosas; estaminódios ausentes; ovário 6-7 mm compr., séssil; estilete $9 \mathrm{~mm}$ compr., puberulento. Legumes $85-95 \times 5 \mathrm{~mm}$, glabros, deiscentes. Sementes 5;3 $32 \mathrm{~mm}$, reniformes a circular, marrons.

Ocorre da América Central ao norte da Argentina (Maréchal et al. 1978). No Brasil ocorre nas regiões Norte (AM, PA, RO), Nordeste (BA), Centro-Oeste (DF, GO, MS, MT), Sudeste (MG, SP) e Sul (PR, RS), nos seguintes Domínios Fitogeográficos: Amazônia, Caatinga, Cerrado, Mata Atlântica, Pantanal (BFG 2015, material suplementar). No PNMJ ocorre na fisionomia Arbustiva Fechada Não Inundável. Coletada com flores e frutos em abril.

Junto com Macroptilium lathyroides (L.) Urb., distinguem-se das demais espécies de trepadeiras do PNMJ por possuirem as pétalas da carena lateralmente torcidas. Diferencia-se de M. lathyroides pelo formato dos folíolos (deltados em A. peduncularis vs. elípticos em M. lathyroides), comprimento do pecíolo (ca. $40 \mathrm{~mm}$ em A. peduncularis vs. $25-30 \mathrm{~mm}$ em M. lathyroides) e cor da corola (lilás em A. peduncularis vs. vinácea em $M$. lathyroides). O gênero Ancistrotropis é caracterizado pelas carenas curvadas em formato de gancho (Delgado-Salinas et al. 2011). Este é o primeiro registro de ocorrência desta espécie para o PNMJ.

Material examinado: BRASIL, ESPÍRITO SANTO, Vila Velha, Parque Natural Municipal de Jacarenema, 20.IV.2011, L.A. Silva 01 (VIES).

3.6 Andira fraxinifolia Benth., Comm. Legum. Gen.: 44. 1837.

Arbustos ca. 2,5 m alt.; ramos sulcados, puberulentos, inermes. Estípulas $0,9 \times 0,6 \mathrm{~mm}$, triangulares, livres, decíduas. Folhas imparipinadas, 7-9-folioladas; pecíolos 20-40 mm compr., glabrescentes; raque foliar $40-70 \mathrm{~mm}$ compr., glabra; folíolos 30-55 × 13-20 mm, elípticos a estreitamente elípticos, base arredondada a aguda, ápice acuminado a cuspidado, margem inteira, faces adaxial e abaxial glabras; nectários foliares ausentes. Inflorescências 
e flores não observadas. Drupas 4,5-5 × 3-3,5 cm, glabras, indeiscentes. Sementes 1, elípticas, 28-35 × 25-30 mm, castanhas a alaranjadas.

Espécie endêmica do Brasil, ocorrendo nas regiões Nordeste (AL, BA, CE, PB, PE, RN, SE), Centro-Oeste (DF, GO), Sudeste (ES, MG, RJ, SP) e Sul (PR, RS, SC) (Pennington 2003; BFG 2015, material suplementar). Habita a Caatinga, Cerrado, Mata Atlântica, Restinga, Mata Atlântica, Campo Rupestre e Áreas em Regeneração (Pennington 2003; BFG 2015, material suplementar). No PNMJ ocorre na formação Arbustiva Aberta Não Inundável. Coletada com frutos em maio e de agosto a outubro.

Diferencia-se das demais espécies do PNMJ pelo fruto do tipo drupa. Distingue-se de Andira nitida, espécie simpátrica no Parque, por possuir folhas 7-9-folioladas (vs. 5-7 folíolos em $A$. nitida), folíolos menores (30-55 $\times$ $13-20 \mathrm{~mm}$ vs. $50-80 \times 35-20 \mathrm{~mm})$ e frutos maiores $(4,5-5 \times$ 3-3,5 cm vs. $2-4 \times 1,9-2,8 \mathrm{~cm})$.

Material examinado: BRASIL, ESPÍRITO SANTO, Vila Velha, Parque Natural Municipal de Jacarenema: 17.IX.2010, B.Z. Rohor 05 (VIES); 03.V.2011, L.A. Silva 010 (VIES); 01.X.2010, L.A. Silva et al. 86 (VIES); 14.VIII.2013, L.A. Silva 373 (VIES).

3.7 Andira nitida Mart. ex Benth., Comm. Legum. Gen.: 45. 1837.

$$
\text { (Fig. 5L) }
$$

Arbustos, 1-2,5 m alt.; ramos, glabros, inermes. Estípulas ca. $4 \times 1 \mathrm{~mm}$, triangulares, livres, decíduas. Folhas imparipinadas, 5-7 folioladas; pecíolos 25-40 mm compr., glabros; raque foliar $60-70 \mathrm{~mm}$, glabra; folíolos 50-80 × 35-20 mm, lanceolados, base arredondada, ápice agudo, margem inteira, faces abaxial e adaxial glabras; nectários foliares ausentes. Inflorescências paniculadas, 80-120-floras, terminais. Flores papilionadas, pentâmeras, não ressupinadas; cálice gamossépalo, ca. 4-6 × 4-5 mm, campanulado, roxo, glabro; corola dialipétala; lilás, vexilo ca. $10 \times 10 \mathrm{~mm}$, alas ca. $12 \times 4 \mathrm{~mm}$, carenas ca. $10 \times$ $3,5 \mathrm{~mm}$, não espiraladas; estames 10 , diadelfos, ca. 11 mm compr., heterodínamos; anteras uniformes, ca. 0,7 mm compr., rimosas; estaminódios ausentes; ovário ca. $5 \mathrm{~mm}$ compr., séssil, glabro; estilete ca. 3,5 mm compr., pubescente. Drupas 2-4 × 1,9-2,8 cm, glabras, indeiscentes. Sementes 1 , esféricas, $15 \times 35 \mathrm{~mm}$ compr., castanhas.

Espécie de distribuição restrita ao Brasil ocorrendo nas regiões Nordeste (AL, BA, PE, SE) e Sudeste (ES, $\mathrm{RJ}$ ), no Domínio Fitogeográfico Mata Atlântica (BFG 2015, material suplementar). No PNMJ ocorre na formação Arbustiva Aberta Não Inundável. Coletada com flores em abril e maio e frutos em abril, maio e outubro.

Assemelha-se à $A$. fraxinifolia, pelo fruto do tipo drupa. Os caracteres que diferenciam estas espécies foram discutidos anteriormente.

Material examinado: BRASIL, ESPÍRITO SANTO, Vila Velha, Parque Natural Municipal de Jacarenema, 21.V.2011, L.A. Silva 014 (VIES); 21.V.2011, L.A. Silva 017 (VIES);
21.V.2011, L.A. Silva 019 (VIES); 01.IV.2012, L.A. Silva \& P.H.D. Barros 206 (VIES); 01.IV.2012, L.A. Silva \& P.H.D. Barros 209 (VIES);

3.8 Canavalia parviflora Benth., Fl. Bras. 15(1): 177. 1862. (Fig. 4A)

Trepadeiras; ramos glabros, inermes. Estípulas não observadas, decíduas. Folhas imparipinadas, 3-folioladas; pecíolos ca. $30 \mathrm{~mm}$ compr., glabros; raque foliar 7-8 mm compr., glabra; folíolos 47-67 × 32-39 mm, elípticos, base retusa, oblíqua ou arredondada, ápice acuminado, cuspidato ou arredondado, margem inteira, faces abaxial e adaxial glabras; nectários foliares ausentes. Inflorescências racemosas, ca. 34-50-floras, axilares. Flores papilionadas, pentâmeras, ressupinadas; cálice gamossépalo, 7,8 × 3,4 $\mathrm{mm}$, tubuloso, verde, glabro; corola dialipétala, lilás a rosa, vexilo ca. $18 \times 15 \mathrm{~mm}$, alas ca. $14 \times 4 \mathrm{~mm}$, carenas ca. $5 \times 13 \mathrm{~mm}$, não espiraladas; estames 10 , monadelfos, ca. $16 \mathrm{~mm}$ compr., heterodínamos; anteras uniformes, ca. $1 \mathrm{~mm}$ compr., rimosas; estaminódios ausentes; ovário ca. $11 \mathrm{~mm}$ compr., estipitado, puberulento; estilete ca. $4 \mathrm{~mm}$ compr., glabro. Legumes 10,4-11,8 × 2,9-3,1 cm, costados, glabros, deiscentes. Sementes não observadas.

Endêmica do Brasil (Sauer 1964) ocorrendo nas regiões Nordeste (AL, BA, PE), Centro-Oeste (DF) e Sudeste (ES, MG, RJ, SP), nos Domínios Fitogeográficos da Caatinga, Cerrado e Mata Atlântica (Sauer 1964, BFG 2015, material suplementar). No PNMJ ocorre em área Herbácea não inundável. Coletada com flores e frutos em julho.

Difere de Canavalia rosea (Sw.) DC. por ser uma trepadeira (enquanto $C$. rosea é uma erva prostrada), além de possuir frutos maiores $(10,4-11,8 \times 2,9-3,1 \mathrm{~cm} v s .6,0$ $9,5 \times 0,8-1 \mathrm{~cm}$ em $C$. rosea). Este é o primeiro registro de ocorrência desta espécie para o PNMJ.

Material examinado: BRASIL. ESPÍRITO SANTO: Parque Natural Municipal de Jacarenema: Vila Velha, 20.VII.2008, H.C. de Lima et al. 7006 (RB).

\subsection{Canavalia rosea (Sw.) DC., Prodr. 2: 404. 1825.}

Ervas prostradas; ramos verdes, glabros, inermes. Estípulas 1-2,5 × 2,5 mm, triangulares, livres, decíduas. Folhas imparipinadas, 3-folioladas; pecíolos 6-10 mm compr., esparso-tomentosos; raque foliar 28-46 mm compr., puberulenta; folíolos 45-90 × $60 \mathrm{~mm}$, amplamente ovados, base obtusa, ápice arredondado, margem inteira, faces adaxial e abaxial esparso-puberulentas. Inflorescências racemosas, 14-20-floras, terminais. Flores papilionadas, pentâmeras, ressupinadas, axilares; cálice gamossépalo, ca. $10 \mathrm{~mm}$ compr., infundibuliforme, verde, esparsopuberulento; corola dialipétala, rosa, vexilo 15-20 × 16-18 mm compr., alas 14-16 $\times 4$ mm compr., carenas 16-20 $\times 8$ mm compr., não espiraladas; estames 10 , monadelfos, ca. $30 \mathrm{~mm}$ compr., homodínamos; anteras uniformes, ca. $2 \mathrm{~mm}$ compr., rimosas; estaminódios ausentes; ovário ca. $16 \mathrm{~mm}$ compr., séssil, glabro; estilete ca. 10 mm compr., glabro. 
Legumes 6,0-9,5 × 0,8-1 cm, costados, puberulentos, deiscentes. Sementes 4-6, reniformes, 3-4 mm compr., marrons pintalgadas de branco.

Espécie de ampla distribuição, ocorrendo na África, Ásia, Austrália, Estados Unidos, México, Américas Central e do Sul (Beyra et al. 2004). No Brasil ocorre nas regiões Norte (PA), Nordeste (AL, BA, CE, MA, PB, PE, RN, $\mathrm{SE}$ ), Sudeste (ES, RJ, SP) e Sul (PR), nos Domínios Fitogeográficos da Amazônia e Mata Atlântica (BFG 2015, material suplementar). No PNMJ ocorre em vegetação Herbácea não inundável. Coletada com flores em abril e outubro e frutos em março e outubro.

Diferencia-se das demais espécies do PNMJ por possuir corola ressupinada e rosa. Os caracteres que podem diferenciá-la de $C$. parviflora foram discutidos anteriormente.

Material examinado: BRASIL, ESPÍRITO SANTO, Vila Velha, Parque Natural Municipal de Jacarenema, 17.IX.2010, B.Z. Rohor 03 (VIES); 20.IV.2011, L.A. Silva 004 (VIES). 03.IX.2011, L.A. Silva 55 (VIES), 01.III.2012, P.H.D. Barros et al. 82 (VIES).

3.10 Centrosema virginianum (L.) Benth., Comm. Legum. Gen.: 56. 1837.

\section{(Fig. 3R)}

Trepadeiras; ramos glabros, inermes. Estípulas ca. $3 \times 1 \mathrm{~mm}$, triangulares, livres, persistentes. Folhas imparipinadas, 3-folioladas; pecíolos 17-20 $\mathrm{mm}$ compr., esparso- puberulentos; raque foliar 0,7-10 mm compr., esparso-puberulenta; folíolos 23-40 × 10-23 $\mathrm{mm}$, elípticos, base arredondada, ápice agudo, margem inteira, faces adaxial e abaxial glabras; nectários ausentes. Inflorescências racemosas, 2-4-floras, axilares. Flores papilionadas, pentâmeras, ressupinadas; cálice gamossépalo, ca. 8-9 × $6 \mathrm{~mm}$, campanulado, verde, puberulento; corola dialipétala, lilás, vexilo 22-31 × 26$28 \mathrm{~mm}$, alas ca. $18 \times 4-5 \mathrm{~mm}$, carenas $18-20 \times 11 \mathrm{~mm}$, não espiraladas; estames 10, diadelfos, ca. 25-30 mm compr., homodínamos; anteras uniformes, ca. 1,5 mm compr., rimosas; ovário ca. $17 \mathrm{~mm}$ compr., séssil, piloso; estilete ca. $8 \mathrm{~mm}$ compr., glabro. Legumes 9,5-12 ×0,37 cm, planos, glabros, deiscentes. Sementes 16-17, reniformes, ca. $4 \times 2 \mathrm{~mm}$, marrons.

Espécie ocorrente nos Estados Unidos, México, sul da Argentina, Brasil e Antilhas. Introduzida na África, sudeste da Ásia e Austrália (Stefano et al. 2008). No Brasil ocorre nas regiões Norte (AC, AM, AP, PA, RO), Nordeste (AL, BA, CE, PB, PE, PI, RN, SE), Centro-Oeste (DF, GO, MS, MT), Sudeste (ES, MG, RJ, SP) e Sul (PR, RS, SC). Ocorre nos Domínios Fitogeográficos da Amazônia e Mata Atlântica (BFG 2015, material suplementar). No PNMJ ocorre em Área Antropizada, Herbácea não inundável e Arbustiva Aberta Não Inundável. Coletada com flores em fevereiro, maio, setembro e novembro e frutos em setembro.

Diferencia-se das demais espécies do PNMJ pelo esporão curto dorsal localizado no estandarte, característica diagnóstica do gênero Centrosema. É frequente na beira da estrada e em áreas antropizadas.

Material examinado: BRASIL, ESPÍRITO SANTO, Vila Velha, Parque Natural Municipal de Jacarenema: 03.V.2011, L.A. Silva 002 (VIES), 13.IX.2010, B.Z. Rohor 07 (VIES), 13.IX.2010, B.Z. Rohor 10 (VIES); 05.XI.2011, L.A. Silva \& Ribeiro, K.S. 68 (VIES); 07.II.2012, L.A. Silva et al. 84 (VIES).

3.11 Clitoria fairchildiana R.A. Howard., Baileya 15(1): 16. 1967.

Arbustos, ca 2,5 m alt.; ramos glabros, inermes. Estípulas $5 \times 2-3 \mathrm{~mm}$ compr., triangulares, livres, decíduas. Folhas imparipinadas, 3-folioladas, pecíolos ca. $45 \mathrm{~mm}$ compr., glabros; raque foliar ca. $21 \mathrm{~mm}$ compr., glabra; folíolos 90-160 × 33-53 mm, elípticos, base arredondada, ápice cuspidato, margem inteira, faces abaxial e adaxial glabras; nectários foliares ausentes. Inflorescências 16-22-floras, terminais. Flores papilionadas, pentâmeras, ressupinadas; cálice gamossépalo, $16 \times 6 \mathrm{~mm}$, tubuloso, verde, glabro; corola dialipétala, lilás, vexilo ca. $40 \times 33$ $\mathrm{mm}$, alas $25 \times 8 \mathrm{~mm}$, carenas $29 \times 7 \mathrm{~mm}$, não espiraladas; estames 10, diadelfos, ca. $30 \mathrm{~mm}$ compr., homodínamos; anteras uniformes, ca. 1,5 mm compr., rimosas; ovário ca. $21 \mathrm{~mm}$ compr., séssil pubescente; estilete ca. $8 \mathrm{~mm}$ compr. Legumes 13-18 × 4-5 cm, glabros, deiscentes. Sementes não observadas.

Ocorrente no Brasil, cultivada nos Estados Unidos, América Central e Filipinas (Fantz 1977). É encontrada em todo o Brasil, exceto nos estados AC, RR e MT, na Amazônia, Caatinga, Cerrado e Mata Atlântica (BFG 2015, material suplementar). No PNMJ ocorre em Mangue degradado e área antropizada. Coletada com flores e frutos em março.

É a única espécie do Parque que possui hábito arbustivo, corola papilionácea e cálice tubuloso. Este é o primeiro registro de ocorrência desta espécie para o PNMJ.

Material examinado: BRASIL, ESPÍRITO SANTO, Vila Velha, Parque Natural Municipal de Jacarenema, 01.III.2012, L.A. Silva 353 (VIES).

3.12 Crotalaria maypurensis Kunth., Nov. Gen. Sp. 6: 403. 1824.

(Fig. 3K)

Subarbustos, ca. $1 \mathrm{~m}$ alt.; ramos puberulentos, inermes. Estípulas $2 \times 0,2 \mathrm{~mm}$, lineares, livres, decíduas. Folhas imparipinadas, 3-folioladas; pecíolos 25-30 mm compr., puberulentos; folíolos 19-31 × 10-20 mm, elípticos, base cuneada, ápice arredondado, margem inteira, face adaxial glabra a esparsamente puberulenta, face abaxial glabrescente, puberulenta na nervura principal e na margem; nectários foliares ausentes. Inflorescências e flores não observadas. Legumes 3-3,6 × 1-1,3 cm, inflados, tomentosos, deiscentes. Sementes ca. 26 , reniformes, $3 \times$ $2 \mathrm{~mm}$, verdes. 
Espécie ocorrente na América Central, Cuba até a América do Sul (Bernal 1986). No Brasil é ocorrente nas regiões Norte (AC, PA, RO, RR, TO), Nordeste (BA, CE, MA, PI), Centro-Oeste (DF, GO, MS, MT), Sudeste (MG, RJ, SP) e Sul (PR). Habita a Amazônia, Caatinga, Cerrado, Mata Atlântica e Pantanal (BFG 2015, material suplementar). No PNMJ ocorre em Área Herbácea Não Inundável, Arbustiva Aberta Não Inundável e Área Antropizada. Coletada com frutos em março.

Pode ser diferenciada das demais espécies do PNMJ pelo hábito subarbustivo, inflorescência racemosa com flores amarelas papilionáceas e fruto tipo legume, inflado e tomentoso, característica que a diferencia de Crotalaria pallida, que possui frutos glabros a esparso-puberulentos. Este é o primeiro registro de ocorrência desta espécie para o PNMJ.

Material examinado: BRASIL, ESPÍRITO SANTO, Vila Velha, Parque Natural Municipal de Jacarenema, 18.III.2012, L.A. Silva 124 (VIES).

3.13 Crotalaria pallida Aiton, Hortus Kew. 3: 20. 1789. (Figs. 3L, M)

Ervas a subarbustos, 0,5-2 $\mathrm{m}$ alt.; ramos puberulentos, inermes. Estípulas 0,8-1,3 × 0,1-1 mm, filiformes a triangulares, livres, decíduas. Folhas imparipinadas, 3-folioladas; pecíolos 20-30 mm compr., puberulentos a pubescentes; folíolos 35-52 × 10-25 mm, elípticos a lanceolados, base cuneada ou arredondada, ápice acuminado, arredondado ou mucronado, margem inteira, face adaxial glabra a esparsamente puberulenta, face abaxial pubescente a densamente pubescente; nectários foliares ausentes. Inflorescências 3-30-floras, terminais. Flores papilionadas, pentâmeras, não ressupinadas; cálice gamosépalo, 5,5-8 ×3 mm, campanulado, verde, puberulento; corola dialipétala, amarela, vexilo 9-12 $\times$ 7-11 mm, alas 8-12 × 2-3 mm, carenas $11 \times 3-5 \mathrm{~mm}$, não espiraladas; estames 10 , monadelfos, 7-15 mm compr., homodínamos; anteras dimórficas, 0,4-2,5 mm compr., rimosas; estaminódios ausentes; ovário 5-7 mm compr., estipitado, puberulento a pubescente; estilete $6-9 \mathrm{~mm}$ compr., glabro a pubescente. Legumes 2-3,1 × 0,6-0,8 $\mathrm{cm}$, inflados, glabros ou esparso-puberulentos, deiscentes. Sementes 13, reniformes, $3 \times 3 \mathrm{~mm}$, marrom-escuras.

Espécie nativa dos trópicos até o Velho Mundo (Flores 2004). No Brasil é ocorrente nas regiões Norte (AC, AM, PA, RR), Nordeste (BA, CE, MA, PI), Centro-Oeste (DF, MS, MT), Sudeste (ES, MG, RJ, SP) e Sul (PR, RS, SC). Habita a Amazônia, Cerrado, Mata Atlântica, Pampa (BFG 2015, material suplementar). No PNMJ ocorre em vegetação Herbácea Não Inundável, Arbustiva Aberta Não Inundável e Área Antropizada. Coletada com flores em abril e outubro e frutos em outubro.

Os caracteres que diferenciam as espécies de Crotalaria do PNMJ foram discutidos anteriormente. Este é o primeiro registro de ocorrência desta espécie para o PNMJ.
Material examinado: BRASIL, ESPÍRITO SANTO, Parque Natural Municipal de Jacarenema: Vila Velha, 01.IV.2012, L.A. Silva 218 (VIES); 27.X.2012, L.A. Silva 282 (VIES); 27.X.2012, L.A. Silva 283 (VIES).

3.14 Dalbergia ecastaphyllum ( L. ) Taub., Nat. Pflanzenfam. 3(3): 335. 1894.

(Fig. 5A)

Arbustos escandentes, ca. $3 \mathrm{~m}$ alt.; ramos puberulentos, inermes. Estípulas decíduas, não observadas. Folhas 1-folioladas; pecíolos ca. $10 \mathrm{~mm}$ compr., puberulentos; folíolos $110 \times 44-52 \mathrm{~mm}$, elípticos, base arredondada ou truncada, ápice acuminado, margem inteira, face adaxial esparso-puberulenta a puberulenta, face abaxial puberulenta a pubescente; nectários foliares ausentes. Inflorescências paniculadas, 7-9-floras, axilares. Flores papilionadas, pentâmeras, não ressupinadas; cálice gamossépalo, 3-4 × $4 \mathrm{~mm}$, campanulado, verde a marrom, puberulento; corola dialipétala, vexilo 6-7 ×5,5 mm., alas ca. $6 \times 2,2 \mathrm{~mm}$, carenas ca. $6 \times 2,8 \mathrm{~mm}$, não espiraladas, branca; estames 10, diadelfos; homodínamos; anteras uniformes, ca. $6 \mathrm{~mm}$ compr, rimosas; ovário ca. $4 \mathrm{~mm}$ compr., séssil, piloso; estilete ca. $6 \mathrm{~mm}$ compr. Legumes samaróides 2,5-2,7 × $2 \mathrm{~cm}$, puberulentos, indeiscentes. Sementes 1 , reniformes, ca. $15 \times 8 \mathrm{~mm}$ compr., marrons.

Esta espécie distribui-se dos Estados Unidos ao Brasil e no oeste da África (Carvalho 1997). No Brasil é ocorrente nas regiões Norte (AM, PA), Nordeste (AL, BA, CE, MA, PB, PE, RN, SE), Sudeste (ES, RJ, SP) e Sul (PR, RS, SC), nos Domínios Fitogeográficos da Amazônia e Mata Atlântica (BFG 2015, material suplementar). No PNMJ ocorre em Mangue e em vegetação Herbácea não inundável. Coletada com flores em setembro e outubro e frutos em abril e setembro.

São características diagnósticas desta espécie o hábito escandente, as flores de cor branca e os legumes samaróides de formato circular, de semente única e com núcleo seminífero central. Este é o primeiro registro de ocorrência desta espécie para o PNMJ.

Material examinado: BRASIL, ESPÍRITO SANTO, Vila Velha, Parque Natural Municipal de Jacarenema, 17.IX.2010, B.Z. Rohor 04 (VIES); 20.IV.2011, L.A. Silva \& J.M.L. Gomes 07 (VIES), 03.IX. 2011, L.A. Silva 52 (VIES); 01.X.2011, L.A. Silva et al. 87 (VIES),

3.15 Desmodium adscendens (Sw.) DC., Prodr. 2: 332.1826. (Fig. 3O)

Ervas; até $20 \mathrm{~cm}$ alt., ramos tomentosos a puberulentos, inermes. Estípulas ca. 4-5 × 1,5 mm, triangulares, livres, persistentes. Folhas imparipinadas, 3 -folioladas; pecíolos ca. $14 \mathrm{~mm}$ compr., pubescentes; raque foliar 5-1 mm compr., pubescente a puberulenta; folíolos 28-34 × 13-18 $\mathrm{mm}$, elípticos, lanceolados ou orbiculares, base obtusa ou arredondada, ápice arredondado ou agudo, margem 
inteira, face adaxial glabra, puberulenta nas bordas, face abaxial puberulenta, principalmente nas nervuras. Inflorescências pseudoracemosas, 13-20-floras, terminais. Flores papilionadas, pentâmeras, não ressupinadas; cálice gamossépalo, 2-3,3 × $2 \mathrm{~mm}$, campanulado, puberulento, verde; corola dialipétala, rosa, vexilo $4-7 \times 3,7-5 \mathrm{~mm}$, alas 4,3-6 × 1-2 mm, carenas 4-7,5 × 1-2 mm, não espiraladas; estames 10, diadelfos, ca. 2,3-5 mm compr., heterodínamos; anteras uniformes, ca. 0,25 mm compr., rimosas; ovário ca. 3,7 mm compr., séssil, piloso; estilete ca. 3,7 mm. Lomentos 3-5 articulados, 1,2-2 ×0,3 cm, puberulentos, indeiscentes. Sementes 1 por artículo, reniformes, 2,6 $\times$ 1,8 mm, castanhas.

Espécie ocorrente na África, Ásia tropical, América Central e América do Sul (Lima et al. 2014). No Brasil ocorre nas regiões Norte (AC, AM, AP, PA, RR, TO), Nordeste (AL, BA, CE, MA, PB, PE, PI, RN, SE), CentroOeste (GO), Sudeste (ES, MG, RJ, SP) e Sul (PR, RS, SC). Ocorre nos Domínios Fitogeográficos Amazônia, Caatinga, Cerrado, Mata Atlântica e Pampa (BFG 2015, material suplementar). No PNMJ ocorre em Área Antropizada e Mata Degradada, sendo abundante nos bordos de mata, principalmente nas margens da rodovia que corta o Parque. Coletada com flores em março e novembro e com frutos em março, maio e novembro.

São características diagnósticas do gênero e que distingue a espécie das demais encontradas no PNMJ: o fruto lomento, a flor papilionácea lilás e o hábito herbáceo. Material examinado: BRASIL, ESPÍRITO SANTO, Vila Velha, Parque Natural Municipal de Jacarenema, 20.IV.2011, L.A. Silva 008(VIES); 17.IX.2010, 13.XI.2010, B.Z. Rohor 09 (VIES). 05.XI.2011, L.A. Silva \& K.S. Ribeiro 76(VIES); 05.XI.2011, L.A. Silva \& K.S. Ribeiro 78 (VIES); 18.III.2012, L.A. Silva 131 (VIES).

3.16 Exostyles venusta Schott. Syst. Veg. 4(2, Cur. Post.): 406. 1827.

Arbustos, ca. $3 \mathrm{~m}$ alt.; ramos pubescentes, inermes. Estípulas 1,9-3,2 × 0,5-1,2 mm, sublunadas, livres decíduas. Folhas imparipinadas, 5-9 folioladas; pecíolos 4,5-10 mm compr., pubescentes; raque foliar 29-45 mm compr., pubescente, folíolos $53 \times 23 \mathrm{~mm}$, elípticos, base acuneada, ápice acuminado, margem denteada, faces abaxial e adaxial glabras; nectários foliares ausentes; Inflorescências e flores não observadas. Legumes 14-11 × 2,4 cm, glabros, indeiscentes. Sementes ca. 7, elípticas, ca. $10 \times 0,6 \mathrm{~mm}$, laranjas a marrom-claras.

Espécie com distribuíção do sul dos Estados Unidos à América do Sul e oeste da África (Carvalho 1997). No Brasil ocorre nas regiões Nordeste (BA) e Sudeste (ES, RJ, SP), em Mata Atlântica (BFG 2015, material suplementar). No PNMJ ocorre na formação Arbustiva Fechada Não Inundável. Coletada com frutos em agosto.

A espécie possui como características: a margem da folha denteada, ramos com epiderme descamante e um agrupamento de estípulas no ápice do ramo. Estas características não são encontradas em nenhuma outra espécie de Leguminosae do PNMJ. Este é o primeiro registro de ocorrência desta espécie para o PNMJ.

Material examinado: BRASIL, ESPÍRITO SANTO, Vila Velha, Parque Natural Municipal de Jacarenema, 20.VIII.2008, H.C. de Lima 7005 (VIES, RB).

Material adicional examinado: BRASIL, ESPÍRITO SANTO, Vila Velha, Interlagos, 28.VIII.1995, O. Zambom 97 (VIES).

3.17 Leptolobium tenuifolium Vogel, Linnaea 11: 391. 1837.

(Fig. 5K)

Arbustos, ca. 3,5 m alt.; ramos glabros, inermes. Estípulas não observadas, decíduas. Folhas imparipinadas, 3-7-folioladas; pecíolos ca. $25 \mathrm{~mm}$ compr., glabros; raque foliar 40-45 mm compr., glabra; folíolos $60 \times 26-37 \mathrm{~mm}$, elípticos, base acuminada, ápice acuminado, margem inteira, faces abaxial e adaxial glabras; nectários foliares ausentes. Flores não observadas. Legumes samaroides $3 \times$ $1,4 \mathrm{~cm}$, glabros, indeiscentes. Sementes 1, elípticas, ca. $8 \times 5,5 \mathrm{~mm}$, vermelhas a marrons.

Espécie endêmica do Brasil, ocorrendo nas regiões Nordeste (BA) e Sudeste (ES, RJ), em Mata Atlântica (BFG 2015, material suplementar). No PNMJ ocorre na formação Arbustiva aberta. Coletada com frutos em maio.

Os caracteres diagnósticos para a espécie são os frutos do tipo legume samaroide de formato elíptico. Este é o primeiro registro de ocorrência desta espécie para o PNMJ. Material examinado: BRASIL, ESPÍRITO SANTO, Vila Velha, Parque Natural Municipal de Jacarenema, 03.V.2011, L.A. Silva 11 (VIES).

3.18 Machaerium hirtum (Vell.) Stellfeld, Tribuna Farm. 12: 132.1944.

(Fig. 5N)

Arbustos, ca. 1,5 m alt., ramos pubescentes, armados. Estípulas 2,5 × 2,5 mm, triangulares, espinescentes, livres, persistentes. Folhas paripinadas, 20-34-folioladas; pecíolos 4,5-9 $\mathrm{mm}$ compr., puberulentos; raque foliar 58-104 mm compr., puberulenta; folíolos 10-20 × 3,3$4 \mathrm{~mm}$, estreitamente elípticos, base arredondada, ápice retuso, margem inteira, faces abaxial e adaxial glabras; nectários foliares ausentes. Inflorescências racemosas, ca. 7-17-floras, terminais. Flores papilionadas, pentâmeras, não ressupinadas; cálice gamossépalo, ca. $5 \times 4 \mathrm{~mm}$, campanulado, verde, glabro; corola dialipétala, vexilo ca. $9 \times 6,5 \mathrm{~mm}$, alas ca. $7 \times 4 \mathrm{~mm}$, carenas ca. $9 \times 2,5 \mathrm{~mm}$, não espiraladas, lilás; estames 10, monadelfos, 8-9 mm compr., homodínamos; anteras não observadas; estaminódios ausentes; ovário ca. 5,5 mm compr., estipitado, pubescente; estilete ca. $2 \mathrm{~mm}$ compr., pubescente. Sâmaras ca. $4 \times 1$ $\mathrm{cm}$, glabras, indeiscentes. Sementes não observadas.

Espécie ocorrente no Panamá, Venezuela, Guianas, Brasil, Colômbia, Peru, Bolívia, Paraguai e Argentina 
(Filardi et al. 2013). No Brasil é encontrada nas regiões Norte (AC, AM, PA, TO), Nordeste (AL, BA, CE, MA, PB, PE, PI, RN, SE), Centro-Oeste (DF, GO, MS, MT), Sudeste (ES, MG, RJ, SP) e Sul (PR, SC). Habita os Domínios Fitogeográficos da Amazônia, Caatinga, Cerrado, Mata Atlântica e Pantanal. (BFG 2015, material suplementar). No PNMJ ocorre em Mata Degradada. Coletada com frutos em março.

Machaerium hirtum, juntamente com M. lanceolatum são as únicas espécies ocorrentes no PNMJ que possuem frutos do tipo sâmara. As diferenças morfológicas entre estas espécies são o hábito arbustivo, estípulas espinescentes, folhas paripinadas, 20-34-folioladas em M. hirtum vs. hábito escandente, estípulas não espinescentes, folhas imparipinadas, 5-folioladas em M. lanceolatum.

Material examinado: BRASIL, ESPÍRITO SANTO, Vila Velha, Parque Natural Municipal de Jacarenema, 18.III.2012, L.A. Silva 123 (VIES).

3.19 Machaerium lanceolatum (Vell.) J.F.Macbr., Publ. Field Mus. Nat. Hist., Bot. Ser. 13, pt. 3: 281. 1943.

(Fig. 5J)

Arbustos escandentes, ca. $3 \mathrm{~m}$ alt.; ramos glabros, lenticelados, inermes. Estípulas não observadas, decíduas. Folhas imparipinadas, 5-folioladas; pecíolos 40-45 mm compr., glabros; raque foliar 22-57 mm compr., glabra; folíolos 50-102 × 32-68 mm, elípticos a largamente elípticos, base acuminada, ápice acuminado, margem inteira, faces abaxial e adaxial glabras; nectários foliares ausentes. Inflorescências e flores não observadas. Sâmaras $4,5 \times 1,2-1,5 \mathrm{~cm}$, glabras, indeiscentes. Sementes 1 , obovadas, ca. 2,5 × 1,3 mm, oliváceas.

Espécie endêmica do Brasil, ocorrente nas regiões Nordeste (BA, PE), Centro-Oeste (DF, GO), Sudeste (ES, MG, RJ, SP) e Sul (PR). Habita os Domínios Fitogeográficos do Cerrado, Mata Atlântica, Floresta Ciliar ou Galeria, Floresta Estacional Decidual, Floresta Ombrófila e Restinga (BFG 2015, material suplementar). No PNMJ ocorre na formação Arbustiva Aberta Não Inundável, sobre substrato arenoso. Coletada com frutos em maio.

As diferenças morfológicas usadas para distinguir Machaerium hirtum e M. lanceolatum foram discutidas anteriormente. Este é o primeiro registro de ocorrência desta espécie para o PNMJ.

Material examinado: BRASIL, ESPÍRITO SANTO, Vila Velha, Parque Natural Municipal de Jacarenema, 03.V.2011, L.A. Silva 09 (VIES); 20.VIII.2008, H.C. de Lima 7008 (RB).

3.20 Macroptilium lathyroides (L.) Urb., Symb. Antill. 9: 457. 1928.

Trepadeiras; ramos puberulentos, inermes. Estípulas 6-7,5 $\times 1,4-2 \mathrm{~mm}$, triangulares, livres, persistentes. Folhas imparipinadas, 3-folioladas; pecíolos 25-30 mm compr., puberulentos; raque foliar 7-10 $\mathrm{mm}$ compr., pubescente; folíolos 36-49 × 18-21 mm, elípticos, base aguda a obtusa, ápice agudo, margem inteira, face abaxial puberulenta e face adaxial glabra; nectários foliares ausentes. Inflorescências racemosas, 11-15-floras, terminais. Flores papilionadas, assimétricas, pentâmeras, não ressupinadas; cálice gamossépalo, 5,4-8 × 1,4-2 mm, tubular, verdeclaro, puberulento; corola dialipétala, ca. 15,5 × $24 \mathrm{~mm}$, vexilo 13,8-15,5 × 9-9,5 mm, alas 23,0-23,5 × 9,5-12 $\mathrm{mm}$, carenas $13-16 \times 2,5-5,5 \mathrm{~mm}$, espiraladas, vinácea; estames 10, diadelfos, 14-15 mm compr., homodínamos; tubo estaminal ca. $11,5 \mathrm{~mm}$ compr., anteras uniformes, 0,5 mm compr., rimosas; estaminódios ausentes; ovário 13-16 $\mathrm{mm}$ compr., não estipitado, pubescente; estilete ca. $6 \mathrm{~mm}$ compr., puberulento. Frutos não observados.

Ocorre em toda a América na região tropical (Maréchal et al. 1978). Não endêmica do Brasil ocorrente nas regiões Norte (AM, PA, RR), Nordeste (AL, BA, CE, MA, PB, PE, PI), Centro-Oeste (DF, GO, MS, MT), Sudeste (ES, MG, RJ, SP) e Sul (PR). Habita os Domínios Fitogeográficos da Amazônia, Cerrado, Mata Atlântica, Pantanal, Área Antrópica, Caatinga (stricto sensu), Floresta Ciliar ou Galeria, Floresta Estacional Semidecidual, Floresta Ombrófila (= Floresta Pluvial) e Restinga (BFG 2015, material suplementar). No PNMJ ocorre na formação Arbustiva Aberta Inundável. Coletada com flores em outubro.

Vegetativamente pode ser confundida com as espécies do gênero Canavalia, mas podem ser diferenciadas pelo indumento dos ramos (ramos puberulentos em Macroptilium vs. ramos glabros em Canavalia). As diferenças morfológicas usadas para distinguir Ancistrotropis peduncularis e Macroptilium lathyroides foram discutidas anteriormente. Este é o primeiro registro de ocorrência desta espécie para o PNMJ.

Material examinado: BRASIL, ESPÍRITO SANTO, Vila Velha, Parque Natural Municipal de Jacarenema, 27.X.2012, L.A. Silva 284 (VIES).

3.21 Rhynchosia phaseoloides (Sw.) DC., Prodr. 2: 385. 1825.

Ervas, ca. 50-40 cm alt.; ramos puberulentos, inermes. Estípulas 1,4-1,7 ×0,1 mm, triangulares, livres, persistentes. Folhas imparipinadas, 3-folíoladas, pecíolos ca. 5,5 mm compr., puberulentos; raque foliar 2,5-1 mm compr., pubescente, com glândulas puntiformes; folíolos 10-12 × 8-9 mm, lanceolados a rômbicos, base arredondada a obtusa, ápice agudo a acuminado, margem inteira, faces adaxial e abaxial glabras a esparso-puberulentas, pubescente nos bordos, com glândulas puntiformes; nectários foliares ausentes. Inflorescências e flores não observadas. Legumes ca. $1,4 \times 0,5 \mathrm{~cm}$, puberulentos, deiscentes. Sementes 2, reniformes, $2,7 \times 2 \mathrm{~mm}$, pretas.

Ocorre do norte e nordeste da Argentina até a América Central (Hirt \& Flores 2012). No Brasil ocorre nas regiões Norte (AC, AM, PA, RO), Nordeste (AL, BA, CE, MA, $\mathrm{PB}, \mathrm{PE}, \mathrm{RN}$ ), Centro-Oeste (DF, MS, MT), em todos os 
Estados do Sudeste e no Sul (PR, SC), nos Domínios Fitogeográficos da Amazônia, Caatinga, Cerrado e Mata Atlântica (BFG 2015, material suplementar). No PNMJ ocorre em Mata Degradada. Coletada com frutos em março.

Possui como característica exclusiva entre as espécies encontradas do PNMJ, a presença de glândulas puntiformes no limbo foliar. Este é o primeiro registro de ocorrência desta espécie para o PNMJ.

Material examinado: BRASIL, ESPÍRITO SANTO, Vila Velha, Parque Natural Municipal de Jacarenema, 01.VI.13, L.A. Silva 133 (VIES).

3.22 Sesbania virgata (Cav.) Poir., Encycl. 7: 129. 1906.

Arbustos, ca. 1,8 m alt.; ramos glabros a pubescentes, inermes. Estípulas não observadas, decíduas. Folhas paripinadas, 36-42-folioladas; pecíolos 12-15 mm compr, puberulentos; raque foliar 220-229 mm compr., puberulenta; folíolos 25-38 × 8-13 mm, elípticos, base cuneada, ápice mucronulada, margem inteira, faces abaxial e adaxial glabras; nectários ausentes. Inflorescências racemosas, 20-23-floras, axilares. Flores zigomorfas, pentâmeras, não ressupinadas; cálice gamossépalo, pentâmero, 4,5-5 × 5,5 $\mathrm{mm}$, campanuladas, verdes a amarelas, corola dialipétala, $10 \times 9 \mathrm{~mm}$, vexilo $11 \times 13 \mathrm{~mm}$, alas $12 \times 3,5 \mathrm{~mm}$, carenas 7,9 × 4,6 mm, não espiraladas, amarelas; estames 10, monadelfos, $13 \mathrm{~mm}$ compr., homodínamos; anteras uniformes, 0,4 mm compr., rimosas, estaminódios ausentes; ovário ca. $13 \mathrm{~mm}$ compr., estipitado, 1,8 mm, glabro; estilete 2,0-2,2 mm compr., glabro. Legumes 4,6-5,6 × 0,85-1 cm, 4-angulados, glabros, indeiscentes. Sementes 5 , reniformes, ca. 7,0-7,2 × 4,4-4,5 mm, marrom-claras a marrom-escuras.

Espécie endêmica do Brasil ocorrendo nas regiões Nordeste (AL, BA, PB, PE, PI, SE), Centro-Oeste (DF, GO, MS, MT), Sudeste (ES, MG, RJ, SP) e Sul (PR, RS, SC), nos Domínios Fitogeográficos da Caatinga, Mata Atlântica, Cerrado e Pampa (BFG 2015, material suplementar). No PNMJ ocorre em Floresta Inundável e Floresta Periodicamente Inundável, em borda de estrada. Coletada com flores em agosto.

No PNMJ, Sesbania virgata pode ser diferenciada pelo hábito arbustivo, folhas 36-42-folioladas, inflorescências axilares e flores papilionáceas, amarelas. Este é o primeiro registro de ocorrência desta espécie para o PNMJ.

Material examinado: BRASIL, Espírito Santo, Vila Velha, Parque Natural Municipal de Jacarenema, 29.VIII.2012, L.A. Silva 242 (VIES).

Material adicional examinado: BRASIL, ESPÍRITO SANTO, Guarapari, Parque Natural Municipal do Morro da Pescaria, 20.X.2013, A.C.S. Dal Col 187 (VIES).

3.23 Sophora tomentosa L., Sp. P1. 1: 373. 1753. (Fig. 5G)

Arbustos ca. 1,5 m alt.; ramos glabros, inermes. Estípulas não observadas, decíduas. Folhas imparipinadas, 7-15-folioladas; pecíolos ca. $15 \mathrm{~mm}$ compr., glabros; raque foliar ca. 90 mm compr., faces abaxial e adaxial glabras; folíolos 25-32 × 14-16 mm, elípticos, base arredondada, ápice arredondado, margem inteira, puberulentos; nectários foliares ausentes. Inflorescências racemosas, multifloras, terminais. Flores papilionadas, pentâmeras, não ressupinadas; cálice gamossépalo, ca. $6 \mathrm{~mm}$ compr., campanulado, verde, puberulento; corola dialipétala, vexilo ca. $20 \times 12 \mathrm{~mm}$, alas ca. $12 \times 3 \mathrm{~mm}$, carenas ca. $14 \times 3,7$ $\mathrm{mm}$, não espiraladas, amarela; estames 10 , curtamente monadelfos, ca. 1,4 mm compr., homodínamos; anteras uniformes, ca. 0,7 mm compr., rimosas; ovário ca. $12 \mathrm{~mm}$ compr., séssil, piloso; estilete ca. $3 \mathrm{~mm}$ compr., glabro. Legumes moniliformes, 4-8,5 ×0,7 cm, puberulentos, deiscentes. Sementes 8-9, esféricas, $7 \times 5,6 \mathrm{~mm}$, marrons.

Ocorre no litoral de todas as regiões tropicais do mundo (Peña et al. 2000). No Brasil ocorre nas regiões Norte (AP, PA), Nordeste (AL, BA, CE, MA, PB, PE, RN, SE), Sudeste (ES, RJ, SP) e Sul (PR, RS, SC). Habita os Domínios Fitogeográficos da Amazônia e Mata Atlântica (BFG 2015, material suplementar). No PNMJ ocorre em vegetação Herbácea não inundável. Coletada com flores em abril e setembro, frutos em abril.

Sophora tomentosa é facilmente identificada no PNMJ por ser a única espécie a possuir fruto moniliforme. Este é o primeiro registro de ocorrência desta espécie para o PNMJ. Material examinado: BRASIL, ESPÍRITO SANTO, Vila Velha, Parque Natural Municipal de Jacarenema, 17.IX.2010, B.Z. Rohor 02 (VIES); 20.IV.2011, L.A. Silva 005 (VIES).

3.24 Stylosanthes debilis M.B. Ferreira \& Sousa Costa, Empresa de Pesquisa Agropecuaria de Minas Gerais: 48. 1979.

Ervas prostradas; ramos puberulentos a glabrescentes, inermes. Estípulas 3-4 × 2-2,5 mm, soldadas, amplexicaules, adnatas à base do pecíolo, triangulares; persistentes. Folhas imparipinadas, 3-folioladas; pecíolos ca. 3,5 mm compr., puberulentos; raque foliar ca. $1 \mathrm{~mm}$ compr., puberulenta; folíolos ca. $5 \times 1 \mathrm{~mm}$, lanceolados a ovados, base cuneada, ápice acuminado, margem inteira, faces adaxial e abaxial puberulentas; nectários foliares ausentes. Inflorescências espiciformes, multifloras, terminais. Flores papilionadas, pentâmeras, não ressupinadas; cálice gamossépalo, ca. $6 \times$ $3 \mathrm{~mm}$, infundibuliforme, verde, glabro; corola dialipétala, vexilo ca. $5 \times 3,5 \mathrm{~mm}$, alas ca. $4 \times 1,8 \mathrm{~mm}$, carenas ca. $4,3 \times$ $1,2 \mathrm{~mm}$, não espiraladas, amarela; estames 10 , monadelfos, ca. 3,9 mm compr., heterodínamos; anteras dimórficas, 0,3-0,9 × 0,25-0,4 mm, rimosas; ovário ca. 2,6 mm compr., séssil, glabro; estilete ca. 1,3 mm, glabro. Lomentos, artículos 1, 2,35 × 1,0 mm. Sementes não observadas.

Espécie restrita ao território brasileiro ocorrendo nas regiões Nordeste (BA), Sudeste (MG), nos Domínios Fitogeográficos da Caatinga e Cerrado (Costa 2006; BFG 2015, material suplementar). No PNMJ ocorre na formação Arbustiva Aberta Não Inundável, Mata Degradada e Área Antropizada. Coletada com flores e frutos em maio. 
A espécie aproxima-se de Stylosanthes viscosa, mas distingue-se desta pelos frutos com rostro uncinado no ápice com até 2,5 $\mathrm{mm}$ de comprimento e lomento elipsoide (vs. rostro até $0,5 \mathrm{~mm}$ de comprimento, helicoidal no ápice e artículo superior obovoide) (Costa 2006). Este é o primeiro registro de ocorrência desta espécie para o PNMJ.

Material examinado: BRASIL, ESPÍRITO SANTO, Vila Velha, Parque Natural Municipal de Jacarenema, 03.V.2011, L.A. Silva 015 (VIES).

3.25 Stylosanthes gracilis Kunth, Nov. Gen. Sp. 6: 507. t. 596.1823.

(Figs. 3H, I)

Ervas, ca. $60 \mathrm{~cm}$ alt.; ramos tomentosos, inermes. Estípulas 10-11 × 3,3 mm compr., soldadas, amplexicaules, adnatas à base do pecíolo, persistentes. Folhas imparipinadas, 3-folioladas, pecíolos ca. $3 \mathrm{~mm}$ compr., glabrescentes a pubescentes; raque foliar ca. $1 \mathrm{~mm}$ compr., puberulenta; folíolos 12-27 × 3,9 mm, elípticos a estreitamente elípticos, base acuminada, ápice acuminado, margem inteira, faces adaxial e abaxial esparsamente puberulentas a pubescentes; nectários foliares ausentes. Inflorescências espiciformes, 3-6-floras, terminais. Flores papilionadas, pentâmeras, não ressupinadas; cálice gamossépalo, ca. 3,6 × 1,8 mm compr., infundibuliforme, verde, glabro; corola dialipétala, vexilo ca. $7 \times 5,5 \mathrm{~mm}$, alas ca. $6 \times 1,9 \mathrm{~mm}$, carenas ca. $4,3 \times 1,2$ $\mathrm{mm}$, amarela, estames 10 , ca. $6,3 \mathrm{~mm}$ compr., monadelfos; anteras dimórficas, 1-3 mm compr., rimosas; ovário ca. 3,8 $\mathrm{mm}$ compr., séssil, glabro; estilete ca. $2 \mathrm{~mm}$ compr., glabro. Lomentos, artículos 1, 2,7-3,1 × 1,5-1,9 mm, glabros e papilosos, indeiscentes. Sementes 1, reniformes, 2-2,1 $\times$ 1,5-1,6 mm, negras.

Espécie ocorrente no Bolívia, Brasil, Guiana Francesa, Panamá e Venezuela. (Costa 2006). No Brasil ocorre nas regiões Norte (AP, PA), Nordeste (AL, BA, CE, MA, PE, SE), Centro-Oeste (DF, GO, MS, MT), Sudeste (ES, MG, RJ, SP) e Sul (PR). Habita os Domínios Fitogeográficos da Amazônia, Caatinga, Cerrado e Mata Atlântica (BFG 2015, material suplementar). No PNMJ ocorre na formação Arbustiva Aberta Não Inundável. Coletada com flores e frutos de abril a junho.

Stylosanthes gracilis é por vezes confundida e até considerada sinônimo de S. guianensis (Aubl.) Sw. (Costa 2006), porém, são espécies distintas. S. gracilis possui lomento uni ou biarticulado ( $v s$. sempre uniarticulado em $S$. guianensis), inflorescências sempre terminais (terminais ou axilares em $S$. guianensis) e em $S$. gracilis as folhas caem no início da floração (Costa 2006). Diferencia-se das demais espécies do gênero por possuir folíolos precocemente caducos, ramos com entrenós alongados e revestidos por tricomas híspido-dourados (Fortuna-Perez et al. 2011). Este é o primeiro registro de ocorrência desta espécie para o PNMJ.

Material examinado: BRASIL. ESPÍRITO SANTO: Parque Natural Municipal de Jacarenema: Vila Velha, 03.V.2011, L.A. Silva 011 (VIES); 01.IV.2012, L.A. Silva 140 (VIES).
3.26 Stylosanthes guianensis (Aubl.) Sw., Kongl. Vetensk. Acad. Nya Handl. 10: 301.1789.

Ervas, ca. $60 \mathrm{~cm}$ alt.; ramos tomentosos, inermes. Estípulas 13-15- × 2,7 mm, soldadas, amplexicaules, adnatas à base do pecíolo, triangulares, persistentes. Folhas imparipinadas, 3-folioladas; pecíolos ca. $3 \mathrm{~mm}$ compr., glabrescentes a tomentosos; raque foliar 0,7 $1 \mathrm{~mm}$ compr., puberulenta; folíolos 12-36 $\times 4 \mathrm{~mm}$, elípticos a estreitamente elípticos, base acuminada, ápice acuminado, margem inteira, faces adaxial e abaxial esparso-pubescentes; nectários ausentes. Inflorescências espiciformes, 3-6-floras, terminais. Flores papilionadas, pentâmeras, não ressupinadas; cálice gamossépalo, ca. $3,6 \times 2 \mathrm{~mm}$ compr., infundibuliforme, verde, glabro; corola dialipétala, vexilo ca. $7 \times 5 \mathrm{~mm}$, alas ca. $6 \times 3,5 \mathrm{~mm}$, carenas ca. $4,3 \times 2 \mathrm{~mm}$, amarela; estames 10 , monadelfos, ca. 3,5 mm compr., homodínamos; anteras dimórficas, ca. $0,1 \mathrm{~mm}$ compr., rimosas; estaminódios ausentes; ovário ca. $1 \mathrm{~mm}$ compr., séssil, glabro; estilete ca. $2,5 \mathrm{~mm}$ compr., glabro. Lomentos, artículos 1, 2,5-3 × 1,8-2 mm, papilosos, glabros, puberulentos nas bordas, indeiscentes. Sementes 1 , reniformes, $2 \times 1,3 \mathrm{~mm}$, negras.

Espécie ocorrente na Bolívia, Brasil, Colômbia, México, Costa Rica, Panamá (Costa 2006). No Brasil ocorre nas regiões Norte (AM, PA, RR, TO), Nordeste (AL, BA, CE, MA, PB, PE, PI, RN, SE), Centro-Oeste (DF, GO, MS, MT), Sudeste (ES, MG, RJ, SP) e Sul (PR, SC) (BFG 2015, material suplementar). Habita os Domínios Fitogeográficos da Amazônia, Caatinga, Cerrado, Mata Atlântica, Pampa e Pantanal (BFG 2015, material suplementar). No PNMJ ocorre na Arbustiva Aberta Não Inundável. Coletada com flores e frutos em março, abril e junho.

No PNMJ pode ser confundida com Stylosanthes gracilis. A diferença entre as espécies foi discutida anteriormente.

Material examinado: BRASIL, ESPÍRITO SANTO, Vila Velha, Parque Natural Municipal de Jacarenema, 18.III.2012, L.A. Silva 132 (VIES); 01.IV.2012, L.A. Silva 204 (VIES); 28.VI.2012, L.A. Silva 166(VIES); 01.IV.2012, L.A. Silva 139 (VIES); 01.IV.2012, L.A. Silva 137 (VIES).

\subsection{Stylosanthes scabra Vogel, Linnaea 12: 69. 1838 (Fig. 3J)}

Ervas a subarbustos, $0,8-1,5 \mathrm{~m}$ alt.; ramos pilosos, esparso-tomentosos, glandulosos, inermes. Estípulas ca. $7 \times 1 \mathrm{~mm}$, soldadas, amplexicaules, adnatas à base do pecíolo, triangulares, persistentes. Folhas imparipinadas, 3-folioladas; pecíolos 5-7 $\mathrm{mm}$ compr., pilosos; raque foliar ca. $1 \mathrm{~mm}$ compr., puberulenta; folíolos $8-17 \times 3,5 \mathrm{~mm}$, lanceolados, base arredondada, ápice acuminado, margem inteira, face adaxial glabrescente, face abaxial esparsopuberulenta; nectários foliares ausentes. Inflorescências espiciformes, multifloras, terminais. Flores papilionadas, pentâmeras, não ressupinadas; cálice gamossépalo, ca. 6-7,9 $\times 1-\mathrm{mm}$, infundibuliforme, verde, glabro; corola 
dialipétala, vexilo ca. 9,6 $\times 4,2 \mathrm{~mm}$, alas ca. $8 \times 3 \mathrm{~mm}$, carenas ca. $10,4 \times 3 \mathrm{~mm}$, amarela; estames 10 , monadelfos, ca. 4,6 mm compr. homodínamos; anteras dimórficas, 0,10,6 mm compr., rimosas; ovário ca. 2,8 mm compr., séssil, glabro; estilete ca. 1,7 mm compr., glabro. Lomentos, artículos 2, ca. 3,6 $\times 2 \mathrm{~mm}$, puberulentos, indeiscentes. Sementes 1, reniformes, 1,8 $\times 1,3 \mathrm{~mm}$, castanhas ou beges.

Espécie ocorrente na Argentina, Bolívia, Brasil, Colômbia; Paraguai, Peru, Estados Unidos e Venezuela (Costa 2006). No Brasil ocorre nas regiões Norte (PA, RR), Nordeste (AL, BA, CE, MA, PB, PE, PI, RN), Centro-Oeste (DF, GO, MS, MT), Sudeste (ES, MG, RJ, SP) e Sul (RS) (BFG 2015, material suplementar). Habita os Domínios Fitogeográficos da Amazônia, Caatinga, Cerrado e Mata Atlântica (BFG 2015, material suplementar). No PNMJ ocorre na formação Arbustiva aberta Não Inundável e Mata Degradada. Coletada com flores e frutos de fevereiro a maio.

Diferencia-se das demais espécies do PNMJ por possuir nervuras muito conspícuas na face abaxial da folha, além de seu fruto possuir um rostro mais alongado do que o encontrado nos demais frutos das espécies do gênero. Este é o primeiro registro de ocorrência desta espécie para o PNMJ.

Material examinado: BRASIL, ESPÍRITO SANTO, Vila Velha, Parque Natural Municipal de Jacarenema, 03.V.2011, L.A. Silva 020 (VIES); 18.III.2012, L.A. Silva 134 (VIES).

\subsection{Stylosanthes viscosa (L.) Sw., Prodr. 108. 1788.}

Ervas geralmente prostradas, por vezes eretas; ramos denso-tomentosos, glandulosos, inermes. Estípulas ca. 3 mm compr., soldadas, amplexicaules, adnatas à base do pecíolo, triangulares, persistentes. Folhas imparipinadas, 3-folioladas; pecíolos ca. $1 \mathrm{~mm}$ compr., puberulentos, glandulosos; raque foliar ca. $0,7 \mathrm{~mm}$ compr., puberulenta; folíolos 4-10 × 2-4,5 mm, elípticos, base acuminada, ápice acuminado, margem inteira, face adaxial esparsopuberulenta, face abaxial puberulenta a tomentosa; nectários foliares ausentes. Inflorescências espiciformes, multifloras, terminais. Flores papilionadas, pentâmeras, não ressupinadas; cálice gamossépalo, ca. $5 \times 0,8 \mathrm{~mm}$, infundibuliforme, verde, glabro; corola dialipétala, vexilo ca. $9,6 \times 3 \mathrm{~mm}$, alas ca. $8 \times 1,3 \mathrm{~mm}$, carenas ca. $7,3 \times$ $1,3 \mathrm{~mm}$, amarela; estames 10 , monadelfos, ca. $4 \mathrm{~mm}$, homodínamos; anteras dimórficas, 0,2-0,6 compr., rimosas; ovário ca. 3,6 mm compr., séssil, glabro; estilete ca. 1,5 mm compr., glabro. Lomentos, artículos 2, 2-3 × 1,4-2 mm compr., esparso-puberulentos, indeiscentes. Sementes 1, reniformes, ca. 1,3-2,4 × 0,8-1,1 mm, pretas.

Ocorrente no Brasil, Cuba, Panamá, Guiana Francesa, Honduras Britânicas, México e Venezuela (Costa 2006). No Brasil ocorre em todas as regiões e em todos os Estados, exceto no Acre e no Tocantins. Habita a Amazônia, Caatinga, Cerrado, Mata Atlântica (BFG 2015, material suplementar). No PNMJ ocorre na formação Arbustiva Aberta Não Inundável, Mata Degradada e Área Antropizada. Coletada com flores e frutos durante todo o ano.
Esta espécie é a mais frequente de seu gênero no Parque. São ervas geralmente prostradas, e é a que possui os menores folíolos dentro do gênero. Pode ser identificada por possuir tricomas glandulares no caule e nos ramos.

Material examinado: BRASIL, ESPÍRITO SANTO, Vila Velha, Parque Natural Municipal de Jacarenema, 20.IV.2011, L.A. Silva 003 (VIES); 17.IX.2010, B.Z. Rohor 01 (VIES).

3.29 Swartzia apetala Raddi, Mem. Mat. Fis. Soc. Ital. Sci. Modena, Pt. Mem. Fis. 18(2): 398. 1820.

(Fig. 5M)

Arbustos, 3-5 m alt.; ramos glabros, inermes. Estípulas 5,6-6,5 × 1,0-1,1 mm, estreitamente triangulares, livres, persistentes. Folhas imparipinadas, 5-7-folioladas; pecíolos ca. $75 \mathrm{~mm}$ compr., face abaxial e face adaxial glabras; raque foliar 100-140 mm compr., glabra; folíolos 160-245 × 73-80 mm, estreitamente elípticos, base cuneada, ápice acuminado, margem inteira, glabros; nectários foliares ausentes. Flores não observadas. Folículos ca. $2 \times 1,5 \mathrm{~cm}$, deiscentes. Sementes 1, elipsoides, ca. $9 \times 6 \mathrm{~mm}$, marrons.

Espécie endêmica do Brasil ocorrendo nas regiões Nordeste (BA, SE), Centro-Oeste (DF) e Sudeste (ES, MG, RJ). Habita os Domínios Fitogeográficos da Caatinga, Cerrado e Mata Atlântica (BFG 2015, material suplementar). No PNMJ ocorre em Florestal Não Inundável. Coletada com frutos em outubro.

Swartzia apetala assim como $S$. simplex var. grandiflora, diferenciam-se das demais espécies do PNMJ por possuirem frutos do tipo folículo, de cor laranja e hábito arbustivo. Diferenciam-se pelas folhas com 5 ou 7 folíolos em $S$. apetala vs. 3 folíolos em $S$. simplex var. grandiflora. Este é o primeiro registro de ocorrência desta espécie para o PNMJ.

Material examinado: BRASIL, ESPÍRITO SANTO, Vila Velha, Parque Natural Municipal de Jacarenema, 15.X.2011, L.A. Silva 064 (VIES).

3.30 Swartzia simplex var. grandiflora (Raddi) Cowan, Fl. Neotrop. Monogr. 1: 172. 1968.

(Figs. 5F, I)

Arbustos, ca. $2 \mathrm{~m}$ alt.; ramos glabros, inermes. Estípulas não observadas, decíduas. Folhas imparipinadas, 3-folioladas; pecíolos 20-26 mm compr., glabros; raque foliar 20-23 mm compr., glabra; folíolos 62-112 × 34-52 $\mathrm{mm}$, elípticos, base cuneada, ápice cuspidado, margem inteira, faces abaxial e adaxial glabras; nectários foliares ausentes. Flores não observadas. Folículos ca. 2,4-1,8 $\times$ $1,5 \mathrm{~cm}$, glabros, deiscentes. Sementes 1 , elipsoides, ca. $2 \times$ 1,5-1,4 mm, pretas a marrom-escuras.

Com distribuição no México até a América Central, norte da Colômbia, oeste do Peru e Bolívia e Brasil (Mansano \& Lima 2007), onde ocorre nas regiões Nordeste (BA) e Sudeste (ES, RJ, SP), em Mata Atlântica (BFG 2015, material suplementar). No PNMJ ocorre na 
formação Arbustiva Fechada Não Inundável. Coletada com frutos em junho.

Este táxon possui o fruto do tipo folículo, de cor laranja, folha 3-foliolada e hábito arbustivo, caracteres que a diferencia das demais espécies do PNMJ. Além disso, é exclusiva da área Arbustiva Fechada Não Inundável. Este é o primeiro registro de ocorrência desta espécie para o PNMJ.

Material examinado: BRASIL, ESPÍRITO SANTO, Vila Velha, Parque Natural Municipal de Jacarenema, 13.VI.1989, L.D. Thomaz 489 (VIES).

3.31 Zollernia glabra (Spreng.) Yakovlev, Bot. Zhurn. (Moscow \& Leningrad) 61(9): 1306. 1976.

$$
\text { (Figs. 5C, D) }
$$

Arbustos, 2-4 m alt.; ramos glabros, inermes. Estípulas 10-6 × 3-2 mm, estreitamente elípticas, livres, decíduas. Folhas imparipinadas, 1-folioladas; pecíolos 2-3 mm compr., glabros; folíolos 5-14 × 2,5-7 cm, elípticos, base arredondada a cuneada, ápice agudo, margem inteira, faces abaxial e adaxial glabras; nectários foliares ausentes. Inflorescências racemosas, ca. 6-18-floras, terminais. Flores papilionadas, pentâmeras, não ressupinadas; cálice gamossépalo, ca. $1,5 \times 2,5 \mathrm{~mm}$, irregular, marrom, glabro; corola dialipétala, vexilo ca. $9 \times 5,5 \mathrm{~mm}$, alas ca. $10 \times 3,7 \mathrm{~mm}$, carenas ca. $9 \times 6 \mathrm{~mm}$, rosa; estames 10, livres, $7 \mathrm{~mm}$ compr.; anteras não observadas; estaminódios ausentes; ovário ca. $5,5 \mathrm{~mm}$ compr., estipitado, puberulento; estilete ca. $3,5 \mathrm{~mm}$ compr., puberulento. Folículos $2 \times 1,8 \mathrm{~cm}$, glabros, indeiscentes. Sementes 2-1, esféricas, 1,2 × 1,1 mm, marrons.

Espécie de distribuição restrita ao Brasil ocorrendo da BA até SP, em Mata Atlântica (BFG 2015, material suplementar). No PNMJ ocorre na formação Arbustiva Aberta Não Inundável. Coletada com frutos em agosto.

A espécie pode ser reconhecida pelas folhas 1-folioladas e pelos folículos verdes. Apresenta lenticelas em partes dos ramos. Este é o primeiro registro de ocorrência desta espécie para o PNMJ.

Material examinado: BRASIL, ESPÍRITO SANTO, Vila Velha, Parque Natural Municipal de Jacarenema, 29.VIII.2012, L.A. Silva 239 (VIES); 20.VIII.2008, H.C. de Lima 7007 (RB).

Material complementar: BRASIL, ESPÍRITO SANTO, Vila Velha, Interlagos, 27.XI.1996, O. Zambom 310 (VIES); 11.X.1996, O. Zambom 298 (VIES); 08.VIII.1995, O. Zambom 39 (VIES); Guarapari, Parque Estadual Paulo César Vinha, 25.XI.1999, A.M. Assis 750 (VIES).

3.32 Zornia glabra Desv., Mém. Soc. Linn. Paris 4: 325. 1826.

$$
\text { (Figs. 3E-G) }
$$

Ervas; ramos glabros, inermes. Estípulas ca. $6 \times 3$ $\mathrm{mm}$, estreitamente espatuliformes, livres, persistentes. Folhas paripinadas, 2-folioladas; pecíolos ca. $14 \mathrm{~mm}$ compr., glabros; folíolos $27 \times 7-8 \mathrm{~mm}$, lanceolados, base acuminada, ápice acuminado, margem inteira, faces abaxial e adaxial glabras; nectários foliares ausentes. Inflorescências espiciformes, multifloras, terminais. Flores papilionadas, pentâmeras, não ressupinadas; cálice gamossépalo, ca. $3 \mathrm{~mm}$ compr., campanulado, glabro; corola dialipétala, vexilo ca. $6 \times 9 \mathrm{~mm}$, alas ca. $6 \times 4,4 \mathrm{~mm}$, carenas ca. $9,8 \times$ $3 \mathrm{~mm}$, amarela; estames 10 , monadelfos, ca. $10 \mathrm{~mm}$ compr., homodínamos; anteras dimórficas, 3-4 mm compr., rimosas; ovário ca. $6,5 \mathrm{~mm}$ compr., séssil, glabro; estilete ca. $3,5 \mathrm{~mm}$ compr., glabro. Lomentos $1 \times 0,2 \mathrm{~cm}$, esparso-tomentosos, indeiscentes. Sementes 4-6, orbiculares, $1 \times 1 \mathrm{~mm}$, oliváceas.

Espécie ocorrente na Argentina, Brasil, Guianas (Perez 2009), Suriname e Peru (Mohlenbrock 1961). No Brasil é encontrada nas regiões Nordeste (AL, BA), Sudeste (ES, RJ, $\mathrm{SP})$ e Sul (SC), nos Domínios Fitogeográficos do Cerrado e Mata Atlântica (BFG 2015, material suplementar). No PNMJ ocorre em Área Antropizada e Mata Degradada. Coletada com flores em abril, setembro e novembro.

Esta espécie pode ser facilmente reconhecida pelas bractéolas peltadas. Este é o primeiro registro de ocorrência desta espécie para o PNMJ.

Material examinado: BRASIL, ESPÍRITO SANTO, Vila Velha, Parque Natural Municipal de Jacarenema: 13.XI.2010, B.Z. Rohor 08 (VIES); 20.IV.2011, L.A. Silva 006 (VIES).

\section{AGRADECIMENTOS}

Ao Programa PIIC/Universidade Federal do Espírito Santo, pelas bolsas concedidas ao primeiro autor, ao Herbário RB pelo empréstimo das exsicatas solicitadas, a José Manoel L. Gomes, Rodrigo Theófilo Valadares pela ajuda no início do projeto e a Aline D. Firmino, Diego T. Iglesias, Paulo H. Dettmann e Weverson C. Cardoso pela colaboração em campo.

\section{REFERÊNCIAS}

Almeida Jr., E.B., Olivo, M.A., Araújo, E.L. \& Zickel C.S. 2009. Caracterização da vegetação de restinga da RPPN de Maracaípe, $\mathrm{PE}$, Brasil, com base na fisionomia, flora, nutrientes do solo e lençol freático. Acta Botanica Brasilica 23(1):36-48.

Araújo, D.S.D. \& Lacerda, L.D. 1987. A natureza das restingas. Ciência Hoje 6:42-48.

Araújo, D.S.D., Sá, C.F.C, Fontella-Pereira, J., Garcia, D.S., Ferreira, M.V., Paixão, R.J., Schneider, S.M. \& Fonseca-Kruel, V.S. 2009. Área de Proteção Ambiental De Massambaba, Rio De Janeiro: Caracterização Fitofisionômica e Florística. Rodriguésia 60(1):67-96.

Assis, A.M., Thomaz, L.D. \& Pereira, O.J. 2004a. Fitossociologia de uma floresta de restinga no Parque Estadual Paulo César Vinha, Setiba, município de Guarapari (ES). Revista Brasileira de Botânica 27(2):349-361.

Assis, A.M. 2004b. Florística de um trecho de floresta de restinga no município de Guarapari, Espírito Santo, Brasil. Acta Botanica Brasilica 18(1):191-201.

Barroso, G.M., Morim, M.P., Peixoto, A.L. \& Ichasso, C.L.F. 1999. Frutos e sementes: morfologia aplicada à sistemática de dicotiledôneas. Imprensa Universitária, Viçosa. 443p.

Barneby, R.C. 1991. Sensitivae Censitae. A description of the genus Mimosa L. (Mimosaceae) in the New World. Memoirs of the New York Botanical Garden 65:1-835.

Bernal, H.Y. 1986. Crotalaria (Fabaceae - Faboideae). Universidad Nacional de Colômbia, Colombia. 118 p. 
Beyra, A., Reyes, G., Hernández, L. \& Herrera, P. 2004. Revisión Taxonomica del Género Canavalia DC. (LeguminosaePapilionoideae) en Cuba. Revista de la. Academia Colombiana de Ciencias 28(107):157-175.

Brazil Flora Group - BFG. 2015. Growing knowledge: an overview of Seed Plant diversity in Brazil. Rodriguésia 66(4):1085-1113.

Brummitt, R.K. \& Powell, C.E. 1992. Authors of plant names. Royal Botanic Gardens, Kew. 732p.

Cantarelli, J.R.R., Almeida Jr., E.B., Santos-Filho, F.S. \& Zickel C.S. 2012. Tipos fitofisionômicos e florística da restinga da APA de Guadalupe, Pernambuco, Brasil. Insula Revista de Botânica 41:95-117.

Carvalho, A.M. 1997. A synopsis of the genus Dalbergia (Leguminosae: Dalbergieae) in Brazil. Brittonia 49(1):87-109.

Cerqueira, R. 2000. Biogeografia das restingas. In Ecologia de Restingas e Lagoas Costeiras (F.A. Esteves \& L.D. Lacerda, eds.). Universidade Federal do Rio de Janeiro, Macaé, p. 65-75.

Chagas, A.P., Peterle, P.L., Thomaz, L.D., Dutra, V.F. \& Valadares, R.T. 2014. Leguminosae Caesalpinioideae do Parque Estadual Paulo César Vinha, Espírito Santo, Brasil. Rodriguésia 65(1):99-112.

Colodete, M.F. \& Pereira, O. J. 2007. Levantamento Florístico da restinga de Regência, Linhares/ES. Revista Brasileira de Biociências 5:558560.

Costa, N.M.S. 2006. Revisão do Género Stylosanthes Sw. Tese 235 f., Universidade Técnica De Lisboa, Lisboa.

Dantas, T.V.P., Nascimento-Júnior, J.E., Ribeiro, A.S. \& Prata, A.P.N. 2010. Florística e estrutura da vegetação arbustivo-arbórea das Areias Brancas do Parque Nacional Serra de Itabaiana/Sergipe, Brasil. Revista Brasileira de Botânica 33(4):575-588.

Delgado-Salinas, A., Thulin, M., Pasquet, R., Weeden, N. \& Lavin, M. 2011. Vigna (Leguminosae) sensu lato: the names and identities of the American segregate genera. American Journal of Botany 98(10):1694-1715.

Du Puy, D.J., Phillipson, P.B. \& Rabevohitra, R. 1995. The Genus Delonix (Leguminosae: Caesalpinioideae: Caesalpinieae) in Madagascar. Kew Bulletin 50(3):445-475.

Dutra, V. F., Alves-Araújo, A. \& Carrijo, T. T. 2015. Angiosperm Checklist of Espírito Santo: using electronic tools to improve the knowledge of an Atlantic Forest biodiversity hotspot. Rodriguésia 66(4):1145-1152.

Dutra, V.F., Garcia, F.C.P. \& Lima, H.C. 2008. Mimosoideae (Leguminosae) nos campos rupestres do Parque Estadual do Itacolomi, Minas Gerais, Brasil. Rodriguésia 59(3):573-585.

Fabris, L.C. 1995. Composição florística e fitossociológica de uma faixa de floresta arenosa litorânea do Parque Estadual de Setiba, Município de Guarapari, ES. Dissertação 195f. Universidade Estadual Paulista Júlio de Mesquita Filho. Rio Claro.

Fabris, L.C. \& César, O. 1996. Estudos florísticos em uma mata litorânea no sul do estado do Espírito Santo. Boletim do Museu de Biologia Mello Leitão 5:15-46.

Fabris, L.C. \& Peixoto, A.L. 2013. Sapotaceae das Restingas do Espírito Santo, Brasil. Rodriguésia 64(2):263-283.

Fantz, P.R. 1977. A Monograph of the Genus Clitoria (Leguminosae: Glycineae). University of Florida.

Fernandes, A. 1996. O taxon Aeschynomene no Brasil. Universidade Federal do Ceará, Fortaleza. 130 p.

Fernandes, J.M. 2011. Ingeae Benth. (Leguminosae) no Estado de MG Brasil: Taxonomia, Morfoanatomia de Nectários Extraflorais e Padrões de Distribuição Geográfica. Tese 298 f., Universidade Federal de Viçosa, Viçosa.

Fidalgo, O. \& Bononi, V. L. R. 1989. Técnicas de coleta, preservação e herborização do material botânico. Instituto de Botânica, São Paulo. 62p.

Filardi, F.L.R., Lima, H.C, Klitgaard, B.B. \& Sartori, A.L.B. 2013. Taxonomy and nomenclature of neotropical Machaerium hirtum complex (Leguminosae, Papilionoideae). Brittonia 65(2):154-170.

Flores, A.S. 2004. Taxonomia, números cromossômicos e química de espécies de Crotalaria L. (Leguminosae-Papilionoideae) no Brasil. Tese 201 f, Universidade Estadual de Campinas, São Paulo.FortunaPerez, A.P., Silva, M.J. \& Tozzi, A.M.G.A. 2011. Stylosanthes (Leguminosae-Papilionoideae-Dalbergieae) no estado de São Paulo, Brasil. Rodriguésia 62(3):615-628.

Fraga, C.N. \& Peixoto, A.L. 2004. Florística e ecologia das Orchidaceae das restingas do estado do Espírito Santo. Rodriguésia 55(84):5-20.
Gomes, J.M.L. 2002. Diagnóstico Ambiental Do Parque Natural Municipal De Jacarenema. In Plano de Manejo do Parque Natural Municipal de Jacarenema. Jruano Consultoria e Serviços, Fundão, v. 2, seção 4, p. 1-184.

Hirt, A.P.M. \& Flores, A.S. 2012. O gênero Rhynchosia Lour. (Leguminosae-Papilionoideae) no estado de Roraima, Brasil. Revista Brasileira de Biociências 10(2): 192-197.

Hughes, C. 1998. Monograph of Leucaena (Leguminosae-Mimosoideae). Systematic Botany Monographs 55:1-244.

Instituto de Permacultura e Ecovilas da Mata Atlântica - IPEMA. 2005. Conservação da Mata Atlântica do Estado do Espírito Santo: cobertura florestal e unidades de conservação. Programa Centros para Conservação da Biodiversidade - Conservação Internacional do Brasil. Vitória. 112p.

Irwin, H.S. \& Barneby, R.C. 1982. The American Cassiinae-A synoptical revision of Leguminosae - Tribe Cassieae subtribe Cassiinae in the New World. Memoirs of the New York Botanical Garden 35:1-918.

Lewis, G.P., Schrire, B., Mackinder, B. \& Lock, M. 2005. Legumes of the World. Royal Botanic Gardens, Kew. 577p.

Lima, L.C.P., Queiroz, L.P., Tozzi, A.M.G.A. \& Lewis, G.P. 2014. A Taxonomic Revision of Desmodium (Leguminosae, Papilionoideae) in Brazil. Phytotaxa 169(1): 1-119.

Maciel, N.C. 1990. Praias, dunas e restingas: unidades de conservação da natureza no Brasil. In Anais do II Simpósio de ecossistemas da costa sul e sudeste brasileira: estrutura, função e manejo (Academia de Ciências do Estado de São Paulo, org.). São Paulo, v. 3, p. 326-351.

Magnago, L.F.S, Martins, S.V. \& Pereira, O.J. 2011. Heterogeneidade Florística das Fitocenoses de Restingas nos Estados do RJ e Espírito Santo, Brasil. Revista Árvore 35(2):245-254.

Magnago, L.F.S, Martins, S.V., Schaefer, C.E.G.R. \& Neri, A.V. 2012. Restinga forests of the Brazilian coast: richness and abundance of tree species on different soils. Anais da Academia Brasileira de Ciências 84(3):807-822.

Mansano, V.F. \& Lima, J.R. 2007. O Gênero Swartzia Schreb. (Leguminosae, Papilionoideae) no Estado do RJ. Rodriguésia 58(2):469-483.

Martins, S.E., Rossi, L., Sampaio, P.S.P. \& Magenta, M.A.G. 2008. Caracterização florística de comunidades vegetais de restinga em Bertioga, SP, Brasil. Acta Botanica Brasilica 22(1):249-274.

Mohlenbrock, R. 1961. A monograph of the Leguminous genus Zornia. Webbia 16(1):1-141.

Moreira, A.A.N. \& Camelier, C. 1977. Relevo. In Geografia do Brasil, Região Sudeste, Instituto Brasileiro de Geografia e Estatística, Diretoria Técnica, Rio de Janeiro, v. 3. p. 10.

Nakajima, J. N. \& Semir J. 2001. The Asteraceae in the Parque Nacional da Serra da Canastra, Minas Gerais, Brazil. Brazilian Journal of Botany 24(4):471-478.

Neves, N.R., Oliva, M.A., Centeno, D. da C., Costa, A.C., Ribas, R.F. \& Pereira, E.G. 2009. Photosynthesis and oxidative stress in the restinga plant species Eugenia uniflora L. exposed to simulated acid rain and iron ore dust deposition: Potential use in environmental risk assessment. Science of the Total Environment 407:3740-3745.

Nunes, S.R.D. da S., Garcia, F.C.P., Lima, H.C. \& Carvalho-Okano, R.M. 2007. Mimosoideae (Leguminosae) arbóreas do Parque Estadual do Rio Doce, MG, Brasil: distribuição geográfica e similaridade florística na Mata Atlântica no Sudeste do Brasil. Rodriguésia 58(2):403-421.

Pedley, L. 2001. Alysicarpus (Leguminosae: Desmodieae) in Australia: a taxonomic revision. Austrobaileya 6(1):107-116.

Peña, R.C., Iturriaga, L., Montenegro, G. \& Cassels, B.K. 2000. Aspectos Filogenéticos y Biogeográficos de Sophora Sect. Edwardsia (Papilionatae). Pacific Science 54(2):159-167.

Pennington, T.D. 1997. The Genus Inga. Royal Botanic Gardens, Kew. 844p.

Pennington, R.T. 2003. Monograph of Andira (LeguminosaePapilionoideae). Systematic Botany Monographs 64:1-143.

Pereira, O.J. 1990. Caracterização fitofisionômica da restinga de Setiba Guarapari, ES. In Anais do II Simpósio de ecossistemas da costa sul e sudeste brasileira: estrutura, função e manejo (Academia de Ciências do Estado de São Paulo, org.). Águas de Lindóia, v. 3, p. 207-219.

Pereira, O.J. \& Araújo, D.S.D. 2000. Análise florística das restingas dos Estados do Espírito Santo e RJ. In Ecologia de restingas e lagoas 
costeiras (F.A. Esteves \& L.D. Lacerda, eds.). Universidade Federal do Rio de Janeiro, Macaé, p. 25-63.

Pereira, O.J. \& Assis, A.M. 2000. Florística da restinga de Camburi. Acta Botanica Brasilica 14(1):99-111.

Pereira, O.J., Assis, A. M. \& Souza, R.L.D. 1998. Vegetação da Restinga de Pontal do Ipiranga, Município de Linhares (ES). In Anais do IV Simpósio de Ecossistemas Brasileiros (Academia de Ciências do Estado de São Paulo, org.). Águas de Lindóia, v. 3, p. 117-128.

Pereira, O.J., Borgo, J.H., Rodrigues, I.D. \& Assis, A.M. 2000. Composição florística de uma floresta de restinga no município da Serra-ES. In Anais do V Simpósio de Ecossistemas Brasileiros (Academia de Ciências do Estado de São Paulo, org.). São Paulo, v. 3 , p. 74-83.

Pereira, O.J. \& Zambom, O. 1998. Composição florística da Restinga de Interlagos, Vila Velha (ES). In Anais do IV Simpósio de ecossistemas brasileiros, v. 3 (Academia de Ciências do Estado de São Paulo, org.). Águas de Lindóia, v. 3, p.129-139.

Perez, A.P.F. 2009. O gênero Zornia J.F. Gmel. (Leguminosae, Papilionoideae, Dalbergieae): Revisão Taxonômica das Espécies Ocorrentes no Brasil e Filogenia. Tese 284 f., Universidade Estadual de Campinas, Campinas.

Peterle, P.L., Chagas. A.P., Thomaz, L.D., Dutra, V.F. \& Valadares, R.T. 2015. Leguminosae Mimosoideae do Parque Estadual Paulo César Vinha, Espírito Santo, Brasil. Rodriguésia 66(1):245-257.

Polhill, R.M., Raven, P.H. \& Stirton, C.H. 1981. Evolution and Systematics of the Leguminosae. In Advances in Legume Systematics (R.M. Polhill \& P.H. Raven, eds.). Royal Botanic Gardens, Kew. p. 1-26.

Radford, A.E., Dickison, W.C., Massey, J.R. \& Bell, C.R. 1974. Vascular plant systematics. Harper \& Row, New York. 891p.

Rando, J.G. 2009. Chamaecrista Moench seções Apoucouita, Chamaecrista e Xerocalyx (Leguminosae-“Caesalpinioideae”) na Serra do Cipó, Minas Gerais, Brasil. Tese 107 f., Universidade de São Paulo, São Paulo.

Ribeiro, R.D., Cardoso, D.B.O.S., Lima, H.C. 2015. A New Species of Hymenaea (Leguminosae: Caesalpinioideae) with a Revised Identification Key to the Genus in the Brazilian Atlantic Forest. Systematic Botany 40(1):151-156.

Romero, R. \& Martins, A.B. 2002. Melastomataceae do Parque Nacional da Serra da Canastra, Minas Gerais, Brasil. Revista Brasileira de Botânica 25(1):19-24.

Rudd, V. E. 1955. The American species of Aeschynomene. Contributions from the United States National Herbarium 32(1):1-172.

Sá, C.F.C. 1992. A vegetação da restinga de Ipitangas, Reserva Ecológica Estadual de Jacarepiá, Saquarema (RJ); fisionomia e listagem de Angiospermas. Arquivos do Jardim Botânico do Rio de Janeiro 31:87-102.

Santos-Filho, F.S. 2009. Composição Florística e Estrutural da Vegetação de Restinga do Estado do Piauí. Tese 124 f., Universidade Federal Rural de Pernambuco, Recife.
Santos-Filho, F.S., Almeida Jr, E.B., Melo Bezerra, L.F., Lima, L.F. \& Zickel, C.S. 2011. Magnoliophyta, restinga vegetation, state of Ceará, Brazil. Check List 7(4): 478-485.

Santos-Gonçalves, A.P., Filgueiras, T.S. \& Clark, L.G. 2011. Atractantha shepherdiana, a New Species of Woody Bamboo (Poaceae: Bambusoideae: Bambuseae) from Brazil. Systematic Botany 36(2):310-313.

Sauer, J. 1964. Revision of Canavalia. Brittonia 16(2):106-181.

Silva, E.D. \& Tozzi, A.M.G.A. 2011. Leguminosae in Ombrophilous Dense Forest of Picinguaba Nucleus, Serra do Mar State Park, SP, Brazil. Biota Neotropica. 11(4):299-325.

Simonelli, M. \& Fraga, C.N. 2007. Espécies da Flora ameaçadas de extinção no Estado do Espírito Santo. Ipema, Vitória. 146p.

Siqueira-Silva, A.I., Silva, L.C., Azevedo, A.A. \& Oliva, M.A. 2012. Iron plaque formation and morphoanatomy of roots from species of restinga subjected to excess iron. Ecotoxicology and Environmental Safety 78:265-275.

Souza, W.O., Machado, J.O., Tognella, M.M.P. \& Alves-Araújo, A. 2016. Checklist de Angiospermas do Parque Estadual de Itaúnas, Espírito Santo, Brasil. Rodriguésia 67(3):571-581.

Souza, M.C., Vianna, F.L., Kawakita, K. \& Miotto, S.T.S. 2012. O gênero Aeschynomene L. (Leguminosae, Faboideae, Dalbergieae) na planície de inundação do alto rio Paraná, Brasil. Revista Brasileira de Biociências 10(2):198-210.

Stefano, R.D., Fantz, P.R., Fernández-Concha, G.C. \& Itza, L.L.C. 2008. Centrosema and Clitoria (Leguminosae: Papilionoidae: Phaseoleae: Clitoriinae). In the Mexican Yucatán Peninsula, Including Three Lectotypifications. Vulpia 7:1-15.

Thiers, B. 2011. continuously updated. Index Herbariorum: A global directory of public herbaria and associated staff. New York Botanical Garden's Virtual Herbarium. Disponível em: $<$ http://sweetgum.nybg. org/science/ih/> Acessado em 11.04.2016.

Thomaz, L.D. \& Monteiro, R. 1993. Distribuição de espécies na comunidade halófilapsamófila ao longo do litoral do Estado do Espírito Santo. Arquivos de Biologia e Tecnologia 36(2):375-399.

Torres-Colin, L., Duno-de Stefano, R., \& Gomez-Hinostrosa, C. 2011. The genus Alysicarpus and Desmodium (Fabaceae) in the Yucatan Peninsula, Mexico. Revista Mexicana de Biodiversidad 82(4):1087-1097.

Valadares, R.T., Martins, M.L.L. \& Coelho, M.A.N. 2010. O gênero Anthurium Schott (Araceae) no Parque Estadual Paulo César Vinha, Guarapari, Espírito Santo. Natureza On Line 8:107-113.

Valadares, R.T. \& Sakuragui, C.M. 2016. A família Araceae Juss. nas restingas do Espírito Santo, Boletim do Museu de Biologia Mello Leitão. Nova Série 38(3):187-255.

Valadares, R.T., Souza, F.B.C., Castro, N.G.D., Peres, A.L.S.S., Schneider, S.Z. \& Martins, M.L.L. 2011. Levantamento florístico de um brejoherbáceo localizado na restinga de Morada do Sol, município de Vila Velha, Espírito Santo, Brasil. Rodriguesia 62(4):827-834.

Weiler Jr., 1998. Leguminosae - Faboideae das Restingas do Estado do Espírito Santo. Dissertação 189 f., Universidade Federal do Rio de Janeiro, Rio de Janeiro. 